\title{
Desenvolvimento regional e complementaridade entre as regiôes: Uma análise da matriz de comércio interestadual brasileira nos anos de 2008 e 2011
}

\author{
André Luís Cabral de Lourenço \\ Universidade Federal do Rio Grande do Norte - Natal - Rio Grande do Norte - \\ Brasil \\ ORCID: 0000-0001-6374-7302 \\ Joelson Oliveira Santos \\ Universidade Federal do Rio Grande do Norte - Natal - Rio Grande do Norte - \\ Brasil \\ ORCID: 0000-0001-9689-9505
}

\section{Resumo}

A despeito da constatação de que o desenvolvimento é um processo irregular e que potencializa áreas e/ou regiôes mais dinâmicas, alguns teóricos do chamado desenvolvimento desequilibrado chamam atenção para a questão da complementaridade entre as regiões ao apontarem que, quanto maiores os encadeamentos de uma estrutura produtiva e, consequentemente, maior a complementaridade entre atividades e regiões, maior tende a ser o nível de desenvolvimento das mesmas. Partindo dessa perspectiva e da hipótese de que uma maior integração comercial entre os estados relaciona-se positivamente com maiores níveis de renda, o presente trabalho objetiva analisar os fluxos de comércio interestaduais para o país, mediante a observação das relações comerciais inerentes ao próprio estado, bem como as relações concernentes aos demais nos anos de 2008 e 2011. As informações para construção das análises provêm das matrizes insumoproduto (MIPs) interestaduais de Guilhoto et al. (2010) e Haddad, Gonçalves Júnior e Nascimento (2018), que consistem, respectivamente, na estimação das matrizes de insumoproduto para os vinte e seis estados brasileiros e o Distrito Federal nos anos de 2008 e 2011. A partir da análise empreendida verifica-se que a estrutura de concentração regional do comércio interestadual brasileiro não se modificou significativamente desde 1985. Tais resultados evidenciam o papel concentrador dos fluxos de comércio, polarizados por São Paulo, que exerce forte influência sobre a estrutura espacial e econômica brasileira. Portanto, dada observação do caráter ainda concentrador dos fluxos de comércio, se faz necessária a atuação de políticas públicas que contribuam para a melhoria da integração do mercado nacional.

Palavras-chave: Desenvolvimento Regional. Complementaridade Regional. Comércio Interestadual. Integração Nacional. 


\title{
Regional development and complementarity between regions: An analysis of the Brazilian interstate trade matrix in the years 2008 and 2011
}

\begin{abstract}
Despite the finding that development is an irregular process and enhances more dynamic areas and/ or regions, some theorists of the so-called unbalanced development draw attention to the issue of complementarity between regions by pointing out that the larger the links of a structure and, consequently, greater the complementarity between activities and regions higher the level of their development tends to be. From this perspective and the hypothesis that greater trade integration between states is positively related to higher income levels, this paper aims to analyze the interstate trade flows to the country, by observing the trade relations inherent to the state itself, as well as the relations concerning the others in the years 2008 and 2011. The information for constructing the analyzes comes from the interstate input-output matrices (MIPs) of Guilhoto et al. (2010) and Haddad, Gonçalves Júnior and Nascimento (2018), which consist, respectively, in the estimation of input-output matrices for the twenty-six Brazilian states and the Federal District in the years 2008 and 2011. From the analysis undertaken, the regional concentration structure of the Brazilian interstate commerce has not changed significantly since 1985. These results highlight the concentrating role of trade flows, polarized by São Paulo, which has a strong influence on the Brazilian spatial and economic structure. Therefore, given the still concentrating character of trade flows, it is necessary the action of public policies that contribute to the better integration of the national market.
\end{abstract}

Keywords: Regional Development. Regional Complementarity. Interstate Trade. National Integration.

\section{Desarrollo regional y complementariedad entre regiones: un análisis de la matriz comercial interestatal brasileña en 2008 y 2011}

\section{Resumen}

A pesar del hallazgo de que el desarrollo es un proceso irregular y mejora áreas y/ o regiones más dinámicas, algunos teóricos del llamado desarrollo desequilibrado llaman la atención sobre el tema de la complementariedad entre regiones al señalar que cuanto más grandes son los enlaces de una estructura e, en consecuencia, mayor sea la complementariedad entre actividades y regiones, mayor será el nivel de su desarrollo. Desde esta perspectiva y la hipótesis de que una mayor integración comercial entre los estados se relaciona positivamente con mayores niveles de ingresos, este documento tiene como objetivo analizar los flujos comerciales interestatales hacia el país, observando las relaciones comerciales inherentes al propio estado, así como las relaciones con los demás en los años 2008 y 2011. La información para construir los análisis proviene de las matrices interestatales de insumo-producto (MIP) de Guilhoto et al. (2010) y Haddad, Gonçalves Júnior y Nascimento (2018), que consisten, respectivamente, en la estimación de matrices insumo-producto para los veintiséis estados brasileños y el Distrito Federal en los años 2008 y 2011. Del análisis realizado, se observa que la estructura de concentración regional del comercio interestatal brasileño no ha cambiado significativamente desde 1985. Estos resultados muestran el papel concentrador de los flujos comerciales, polarizados por São Paulo, que tiene una fuerte influencia en la estructura espacial y económica de Brasil. Por lo tanto, dado el carácter aún concentrado de los flujos comerciales, es necesaria la acción de políticas públicas que contribuyan a una mejor integración del mercado nacional.

Palabras clave: Desarrollo Regional. Complementariedad Regional. Comercio Interestatal. Integración Nacional. 


\section{Introdução}

Dada à complexidade das inter-relações existentes dentro de uma determinada localidade e sua relação com as diferentes localidades que a circundam constata-se que o processo de desenvolvimento não ocorre de forma igual e simultaneamente em toda a parte. Apesar de tal constatação, alguns teóricos (FURTADO, 2000; HIRSCHMAN, 1958; MYRDAL, 1968; PERROUX, 1977) chamam atenção para a questão da complementaridade entre as regiões: apesar do desenvolvimento ser um processo irregular, que potencializa áreas e/ou regióes mais dinâmicas e que apresentam maior potencial de crescimento, também verificase a existência de efeitos de transbordamento do crescimento que podem amenizar, neutralizar ou sobrepor os efeitos de polarização do crescimento.

No tocante a esse aspecto, observa-se que as economias regionais não são simplesmente versões em menor escala das economias nacionais. Elas apresentam especificidades tais que se fazem necessárias teorias próprias que versem sobre 0 processo de desenvolvimento regional. Em geral, devido aos contatos mais estreitos e às interações mais intensas que existem entre as regiões de um país, tanto o efeito de transbordamento do crescimento quanto os efeitos de polarização são mais fortes nas relações econômicas inter-regionais do que nas internacionais. Neste sentido, as forças políticas que contribuem para a transmissão inter-regional do crescimento são, provavelmente, mais poderosas do que as que contribuem para a transmissão internacional (HADDAD, 2003).

Portanto, o comércio inter-regional pode tornar-se um propulsor do crescimento regional e/ou perpetuar as disparidades regionais em um determinado país. Nesse sentido, as interações inter-regionais, dentre outros fatores, são importantes ao desenvolvimento de uma região. Logo, é inquestionável a necessidade de um maior número de estudos recentes para tais interações. Contudo, conforme apontam Sousa e Hidalgo (2009) e Galvão (2014), apesar de relevante, o estudo do comércio inter-regional no Brasil apresenta algumas limitações. Segundo os mesmos, há uma carência quanto à disponibilidade de dados sobre os fluxos de comércio por vias internas, consequentemente, estudos sobre o comércio interno e, de modo mais geral, sobre integração econômica regional, são escassos no Brasil.

Dessa forma, dada a importância do tema, e partindo-se da hipótese de que uma maior integração comercial entre os estados relaciona-se positivamente com maiores níveis de renda, este trabalho tem por objetivo analisar os fluxos de comércio interestadual para o país, mediante a observação das relações comerciais inerentes ao próprio estado, bem como as relações concernentes aos demais, nos anos de 2008 e 2011. Compete a este trabalho, portanto, contribuir com a literatura nacional através da análise de um novo período, 2008 e 2011, e sua comparação ao observado anteriormente. Unindo-se ao esforço presente na literatura ao estudo do comércio inter-regional no Brasil.

As informações para construção das análises provêm das matrizes insumoproduto (MIPs) interestaduais de Guilhoto et al. (2010) e Haddad, Gonçalves Júnior e Nascimento (2018), que consistem, respectivamente, na estimação das matrizes de insumo-produto para os vinte e seis estados brasileiros e o Distrito Federal nos anos de 2008 e 2011. 
Além desta introdução e das considerações finais, compõem o trabalho mais três seções. A segunda seção destina-se a apresentação de teorias do chamado desenvolvimento desequilibrado. Para esse trabalho, o objetivo dessa seção não é realizar uma avaliação crítica dessas teorias, nem buscar uma análise mais geral de seus pontos em comum, mas enfatizar, especificamente, o papel da complementaridade entre as regiões dentro de tal análise. Na terceira seção faz-se uma análise de trabalhos que tratam do comércio inter-regional e do processo de integração do mercado nacional, visando compreender melhor seu efeito no comércio brasileiro por vias internas. A quarta seção procura descrever os fluxos de comércio interestaduais para os anos de 2008 e 2011, contribuindo para a verificação da hipótese lançada ao permitir obter-se uma visão geral do sistema inter-regional e intrarregional do comércio interestadual brasileiro, e dos principais fluxos de comércio e da interdependência (no que tange ao comércio) entre as regiões analisadas.

\section{0 pós-Segunda Guerra Mundial, a questão do desenvolvimento regional e o papel da complementaridade entre as regiões no processo de desenvolvimento}

Passado o período de intensa instabilidade político-econômica decorrente das duas guerras mundiais, da pressão exercida pela opção socialista, da necessidade de reestruturação dos países perdedores e da constatação de que o desenvolvimento não ocorre simultânea e igualmente no espaço, a questão do desenvolvimento econômico ganhou crescente notoriedade dentro da agenda dos governos nacionais.

Além do desenvolvimento econômico em geral e da reconstrução econômica europeia e japonesa, no pós-Segunda Guerra, o debate acerca da desigualdade entre países e entre regiões de um mesmo estado nacional acentua-se. A partir de tal acentuação, manifestações relacionadas com o desenvolvimento econômico e com as desigualdades territoriais e sociais deram origem à criação de várias instituições e de instrumentos de política regional, tais como os planos de distribuição territorial e polos de desenvolvimento na França, políticas de desconcentração industrial na Inglaterra, entre outros.

Diniz (2001) aponta que tais experiências tinham como fundamento e base teórica as teorias clássicas da localização ${ }^{1}$ das atividades econômicas de origem alemã (Von Thunen, Weber, Losch, Christaler) e a chamada "Regional Science", capitaneada por Walter Isard (1956). Esse corpo teórico buscou construir uma teoria da localização das atividades econômicas tomando a localização como um problema de condicionalidade espacial, isto é, levando-se em consideração as influências que o espaço geográfico exerce sobre as atividades econômicas, uma vez que estas se encontram, necessariamente, condicionadas pela distribuição espacial dos insumos de produção e proximidade dos mercados consumidores.

No mesmo período, desenvolveu-se, predominantemente na Europa, a análise do chamado desenvolvimento desequilibrado (HIRSCHMAN, 1958; MYRDAL, 1968; PERROUX, 1977). Tal análise enfatiza o caráter desigual do desenvolvimento,

\footnotetext{
${ }^{1}$ Vide Breitbach (1988).

${ }^{2}$ Vide Benko (1999).
} 
evidenciando que o mesmo não ocorre de maneira igual e simultânea em toda a parte. Pelo contrário, advoga que trata-se de um processo irregular e que, uma vez iniciado em determinados pontos, possui a característica de fortalecer essas áreas/regiões em detrimento de outras. Dessa forma, Ribeiro e Brito (2013) advogam que os autores divergem em relação à possibilidade de conciliação do processo de desenvolvimento, tanto em termos teóricos quanto práticos, com as ideias da teoria do desenvolvimento equilibrado, tendo Rosenstein-Rodan (1943) e Nurkse (1953) como seus principais defensores.

Perroux (1977), a partir da observação do desenvolvimento desigual na França, aponta que: "o crescimento não surge em toda parte ao mesmo tempo; manifesta-se com intensidades variáveis, em pontos ou polos de crescimento; propaga-se, segundo vias diferentes e com efeitos finais variáveis, no conjunto da economia" (PERROUX, 1977, p. 164). A partir de tal acepção, para Perroux o desenvolvimento ocorre a partir de polos, cuja dinâmica é determinada por indústrias motrizes que provocam efeitos multiplicadores sobre as demais atividades.

Myrdal (1968), por seu turno, através de sua teoria do processo de causação circular cumulativa, recorre à noção de ciclo vicioso para explicar como um fator negativo é, ao mesmo tempo, causa e efeito de outros fatores negativos. A partir de tal concepção o autor demonstra que o processo de desenvolvimento promove um processo circular e cumulativo através do qual as regiões desenvolvidas tendem a tornar-se ainda mais ricas e as regiões subdesenvolvidas ainda mais pobres: "The concept implies, of course, a circular constellation of forces tending to act and react upon one another in such a way as to keep a poor country in a state of poverty"3 (MYRDAL, 1957, p. 11 apud LIMA; SIMÕES, 2010).

Nesse caso, a partir da teoria do processo de causação circular cumulativa, Lima e Simões (2010b) apontam que se não ocorrerem mudanças exógenas em determinadas localidades que apresentem baixos índices de crescimento e desenvolvimento econômico, as mesmas se tornarão cada vez menos atrativas, de tal forma que seus fatores de produção, capital e trabalho, migrarão em busca de novas oportunidades, provocando uma nova diminuição da renda desses locais.

Similarmente ao trabalho empreendido por Myrdal (1968), Hirschman (1958) analisa o processo de desenvolvimento econômico e como o mesmo pode ser transmitido de uma região para outra. O autor enfatiza que o desenvolvimento de uma localidade gera efeitos de fluência e de polarização em direção às localidades subsequentes.

Os efeitos favoráveis, representados pelos efeitos de fluência, podem ser exemplificados pelo aumento das compras e dos investimentos da região desenvolvida nas demais. Por outro lado, os efeitos desfavoráveis (efeitos de polarização) estão relacionados ao aumento da competitividade da região desenvolvida, implicando na atração de capital e mão de obra qualificada das regiões atrasadas.

\footnotetext{
${ }^{3} \mathrm{O}$ conceito implica, claro, uma constelação circular de forças que tendem a agir e reagir umas sobre as outras de forma a manter um país pobre em estado de pobreza. (TRADUÇÃO NOSSA).
} 
Na América Latina, a partir da concepção de centro e periferia, a CEPAL ${ }^{4}$ advogou que o atraso relativo dos países latino-americanos perante os países centrais decorria da deterioração dos seus termos de intercâmbio no comércio internacional. Nesse caso, conforme se dá o aumento da renda, regiões produtoras de bens primários tenderiam a apresentar crescimento menor em relação às regiões produtoras de bens com maior conteúdo tecnológico. A saída proposta para mitigar tais efeitos era, portanto, a industrialização. Na ausência de uma elite local capaz de levar a frente o processo de industrialização, seja pela escassez de recursos econômicos e técnicos ou pela própria tendência do capital privado de localizar-se em regiões ditas já desenvolvidas, caberia ao Estado promover a industrialização nas regiões periféricas.

Ao traçar-se um ponto em comum, específico ${ }^{5}$, entre as teorias do desenvolvimento desequilibrado observa-se a ênfase dada pelos autores a questão da complementaridade entre as atividades econômicas e, consequentemente, entre as regiões. Perroux assinala a necessidade de se conceberem conexões entre os polos de crescimento situados em pontos diferentes do território: "Quando dois destes centros entram em comunicação graças a vias de transporte material e intelectual, extensas transformações se desenham no horizonte econômico e nos planos de produtores e consumidores" (PERROUX, 1977, p. 175).

Hirschman (1958) acentua que a falta de interdependência setorial e, consequentemente, os baixos linkage effects apontados em sua análise, constituem uma das principais características das economias subdesenvolvidas. No tocante a esse aspecto, o autor enfatiza que os linkage effects são fundamentais para o processo de desenvolvimento. Em oposição aos efeitos regressivos (backwash effects) de quando um centro regional recebe um impulso econômico, Myrdal (1968) aponta que há efeitos propulsores (spread effects) do crescimento que se propagam de uma região em expansão para outras.

Por sua vez, Furtado (2000), autor de vertente cepalina, aponta que a industrialização somente poderá prosseguir se a estrutura da economia, e do setor industrial em particular, houver alcançado certo grau de diversificação, de tal forma que a utilização da capacidade produtiva industrial desencadeie investimentos no conjunto da economia.

Logo, tais teorias enfatizam a importância da complementaridade entre as atividades e/ou regióes de uma determinada localidade como fundamentais para o processo de desenvolvimento. Assim, quanto maiores os encadeamentos de uma estrutura produtiva e, consequentemente, maior a complementaridade entre atividades e regiões, maior tende a ser o nível de desenvolvimento de uma região e/ou país.

Em análise específica para o Brasil, tal qual o apontado pelos teóricos anteriormente analisados, alguns trabalhos de cunho empírico mostram como as interações econômicas das unidades da federação são importantes para o desenvolvimento do país. Nesse caso, Perobelli (2004), por seu turno, examina as

\footnotetext{
${ }^{4}$ Vide Rodriguez (1986).

${ }^{5}$ Como descrito na introdução o objetivo dessa seção não é realizar uma avaliação crítica dessas teorias, nem buscar uma análise mais geral de seus pontos em comum, mas enfatizar, especificamente, o papel da complementaridade entre as regiões dentro de tais análises.
} 
interações econômicas das unidades da federação, através da análise da estrutura do comércio inter-regional brasileiro, entre os anos de 1985 e 1997, bem como suas relações mercantis com o resto do mundo, por meio de um modelo de equilíbrio geral computável $(\mathrm{EGC})^{6}$.

Dentre os resultados da análise empreendida, o autor destaca que, para a maioria dos estados da região Norte, há uma forte dependência em relação à região Sudeste, como mercado importador de produtos produzidos pela região Norte. Quanto à região Sudeste, verifica-se sua maior integração, em termos relativos, com os blocos econômicos de comércio presentes na análise e que a região "possui um número mais diversificado de pontos fortes, principalmente no setor industrial" (PEROBELLI, 2004, p. 180). O autor aponta ainda que os resultados encontrados mostram que as políticas de ampliação das exportações do setor industrial têm maior impacto sobre as economias do Sudeste. Em muitos setores, a função fornecedora de insumos da região Norte pode ser potencializada, de tal forma que os insumos necessários para os produtos produzidos e exportados pelo Sudeste possam ser fornecidos de forma mais eficiente.

Ademais, o autor chama a atenção para a necessidade de que as políticas públicas contribuam para a melhoria da integração da economia brasileira através da readequação da rede de transportes do país. Isto potencializaria a complementariedade das unidades da federação e a inserção das regiões menos desenvolvidas no contexto do comércio internacional. Tais considerações também são apontadas por Almeida e Silva (2007). Ao utilizarem o modelo gravitacional com a finalidade de mensurar e comparar o efeito fronteira existente no comércio entre as regiões brasileiras e seus principais parceiros comerciais internacionais em 1999, Almeida e Silva (2007) assinalam que os estados brasileiros ainda se mostram pouco integrados entre si e ao comércio internacional. Para os autores, há grandes problemas de desigualdades produtivas e de renda no Brasil, que, aliados aos problemas de infraestrutura física e de transportes entre os estados, contribuem significativamente para essa pequena integração comercial.

Perobelli, Haddad e Domingues (2006), através do método de Extração Hipotética aplicado a matriz inter-regional de insumo produto para o ano de 1996, e da análise dos efeitos para trás (backward effects) e para frente (forward effects), concluem que Norte, Nordeste e Centro-Oeste integram um grupo caracterizado por elevada dependência, no que tange à aquisição de insumos e vendas de produtos, do Sudeste e Sul. Em contrapartida, as regiões Sudeste e Sul formam um grupo caracterizado por possuírem alta interdependência regional e uma incipiente dependência em relação às demais regiões brasileiras.

Ao aplicaram o método de Extração Hipotética em matrizes interestaduais de insumo-produto com base nos anos de 1996 e 2002, em conjunto a uma análise exploratória de dados espaciais ${ }^{7}$, Perobelli et al. (2010) chegaram aos seguintes

6 Trata-se de um modelo EGC de tradição australiana (B-MARIA27-IT) composto por seis tipos de agentes (setores produtivos, investidores, famílias, governo federal, governo regional e setor externo), vinte e sete regiões e oito tipos de setores produzindo oito bens. Para maiores detalhes quanto a especificação do modelo vide Perobelli (2004, p. 104-139).

7 Neste trabalho os autores espacializam os resultados do método de extração aplicado à matriz de insumo-produto através do cálculo dos indicadores globais e locais de associação geográfica, para 
resultados: i) para a agricultura, sob a ótica das compras (backward effects), a maioria dos estados apresentou uma redução em seus níveis de dependência, no que concerne à aquisição e venda de produtos, tanto intra quanto intersetoriais, em relação ao restante do país. Todavia, tais alterações não se mostraram significativas ao ponto de alterar a estrutura produtiva existente, exceto no Amazonas; ii) em relação às vendas da agricultura (forward effects), em 1996 houve um fluxo significativo de exportações proveniente da maioria das regiões. Porém, em 2002, esses fluxos diminuíram e se apresentaram mais estáveis, sob os dois aspectos analisados; iii) no que diz respeito às compras do setor industrial, para os efeitos intersetoriais, tem-se o alto grau de dependência da maioria dos estados da região Norte com relação à aquisição de insumos do restante do Brasil (estados importadores). Nas regiões Sudeste e Sul a dependência com relação ao restante do Brasil é bem menor. Quanto aos os efeitos do comércio intrasetorial, tanto os backward effects quanto os forward effects diminuem no período analisado em todas as regiões; iv) sob a ótica das vendas para a indústria, tanto inter como intrasetorial, destacou-se a relevante participação do estado de São Paulo, dado que o fluxo São Paulo - Brasil se mostrou mais expressivo do que o inverso.

Magalhães (2009) buscou avaliar a importância dos fluxos de comércio entre os estados brasileiros, e suas conexões mais relevantes, através de um modelo $\mathrm{EGC}^{8}$. Aplicando tal modelagem, a autora explorou os impactos da redução dos custos de transporte entre os estados, identificando os fluxos mais relevantes para diferentes objetivos de política econômica (crescimento nacional, custos de produção, desigualdade regional, bem-estar social e crescimento regional, neste caso especificamente para o Nordeste).

Ao analisarem-se os impactos do comércio sobre as desigualdades regionais, a autora enfatiza que: i) parece haver um trade-off entre crescimento e redução das desigualdades para muitos dos fluxos, dada a heterogeneidade da integração comercial; ii) para os fluxos de comércio agropecuários, a melhor acessibilidade aos mercados do Nordeste afeta positivamente a diminuição das desigualdades; iii) por outro lado, ao se considerar os resultados para os fluxos industriais, muitos dos fluxos destinados ao Nordeste estão associados ao aumento das desigualdades; iv) ao analisar-se conjuntamente os fluxos comerciais, observa-se que as desigualdades regionais diminuem com o melhor acesso das regiões Norte, Nordeste e CentroOeste aos mercados do Sul e Sudeste.

Quanto à questão concernente ao impacto dos fluxos de comércio sobre o crescimento do Nordeste, os resultados sugerem que, embora a importância da integração intrarregional não seja desprezível, o comércio com as regiões Sul e Sudeste do país pode exercer um papel mais relevante para o crescimento da região.

verificar o quanto a distância importa para os resultados de interações inter-regionais e intrarregionais.

${ }^{8}$ Emprega-se como metodologia um modelo de equilíbrio geral computável multiregional (EGC) para o Brasil - IMAGEM-B. O modelo é bottom-up para os 27 estados e 36 setores, e top-down para os 5507 municípios. Para maiores detalhes quanto à especificação do modelo vide Magalhães (2009, p. 37-67). 


\section{Comércio inter-regional e integração do mercado nacional: o caso brasileiro}

Diante da insuficiência de dados $^{9}$, esta seção destina-se a elucidar alguns achados importantes de trabalhos que tratam dos questionamentos acerca da integração do mercado nacional, bem como do comércio inter-regional em termos brasileiros. Como o trabalho foca sua análise no estudo das inter-relações comerciais para o Brasil, acredita-se que a revisão de trabalhos aqui realizada pode subsidiar a análise posterior a ser desenvolvida.

\subsection{De um arquipélago de ilhas econômicas isoladas à integração do mercado nacional: dos anos 40 à década de 1960}

Pioneiro no que concerne ao estudo da balança comercial inter-regional brasileira, Galvão (1993) analisa o comércio inter-regional e intrarregional através de 4 matrizes do comércio interestadual para os anos de 1943, 1947, 1961 e 1969. Segundo o autor, no que concerne ao destino das exportações, até a metade do século 20, o comércio inter-regional brasileiro era ainda incipiente e a pauta de exportações estaduais voltava-se principalmente ao mercado internacional.

No tocante à natureza das articulações regionais, no Nordeste, Galvão (2014) aponta que em 1943 apenas 5\% das suas exportações tinham como destino as demais regiões do país, enquanto que aproximadamente $17 \%$ de suas importações se originavam de outras regiões. No Sudeste, $12 \%$ de suas exportações e $9 \%$ das importações relacionavam-se a fluxos de comércio inter-regional. No Norte, essas cifras correspondiam a 38 e 48\%, respectivamente, das exportações e importações. As regiões Sul e Centro-Oeste, porém, revelavam um quadro exatamente oposto: estados do Sul, 75 e $76 \%$, respectivamente, de todas as exportações e importações por vias internas, tinham destino e origem transregional, enquanto praticamente todo o comércio do Centro-Oeste ( $99 \%$ dos fluxos nas duas direções) era transregional.

No que diz respeito aos balanços inter-regionais de comércio, observa-se que o Nordeste mantinha uma relação deficitária com todas as demais regiões do país, ao passo que para o Sudeste verifica-se o oposto. Ademais, $87 \%$ do deficit nordestino fora resultante do seu desequilíbrio comercial com a região Sudeste (GALVÃO, 1993, 2014).

A partir dos anos 50 houve uma considerável reversão deste quadro, dado que as relações entre os estados se intensificaram ao ponto do comércio interregional superar o comércio internacional. Galvão (1993), ao comparar as matrizes das décadas de 1940 e as da de 1960, aponta as principais mudanças ocorridas no comércio por vias internas brasileiras: i) em 1947 o comércio transregional das unidades da Federação situava-se em torno de $20 \%$ do total por vias internas. Ao passo que em 1961 e 1969, tais fluxos de comércio aumentam substancialmente, para, respectivamente, $45 \%$ e $47 \%$; ii) o comércio da região Norte, até então predominantemente intrarregional, passou a majoritariamente transregional; iii) no

\footnotetext{
${ }^{9}$ Conforme mencionado na introdução apesar de relevante, o estudo do comércio inter-regional no Brasil apresenta limitações, pois há uma carência quanto à disponibilidade de dados sobre os fluxos de comércio por vias internas (GALVÃO, 2014; SOUSA; HIDALGO, 2009).
} 
Nordeste, apesar da predominância do comércio intrarregional, registrou-se significativa expansão do seu grau de abertura, pois aproximadamente $33 \%$ de suas exportações foram destinadas as demais regiões do país, e cerca de $50 \%$ de suas importações eram oriundas de outras regiões; iv) igualmente expressivo foi o aumento do grau de abertura da região Sudeste, dado que seu comércio transregional, responsável por $12 \%$ do movimento de exportações por vias internas em 1943 e 1947, atinge o patamar de 36\% em 1961; v) as regiões Centro-Oeste e Sul mantiveram os mesmos padrões das décadas anteriores, isto é, um comércio transregional intenso, relativamente ao total de seu comércio por vias internas.

Segundo o autor, antes dos anos 50 o comércio inter-regional no Brasil era pequeno e, praticamente, realizado por meio de cabotagem, o que dificultava a intensificação dos fluxos comerciais entre as regiões brasileiras. Os altos custos da navegação costeira e fluvial, os baixos níveis de confiabilidade dessa modalidade de transporte e as limitações técnicas dos navios brasileiros tornavam o transporte via cabotagem incapaz de unificar os mercados nacionais, sobretudo na fase de maior avanço no processo de industrialização brasileira.

As ferrovias nacionais, por outro lado, desempenhavam papel relevante no desenvolvimento de determinadas regiões e na unificação de alguns mercados regionais. Contudo, as dificuldades inerentes à implantação da malha ferroviária no país, além dos elevados custos operacionais dos sistemas regionais existentes, bem como a manutenção inadequada das linhas férreas "impediram que as ferrovias no Brasil [...] funcionassem como um fator verdadeiramente integrador [...]" (GALVÃO, 1993, p. 524). Para o autor, até então havia uma situação em que o sistema comercial brasileiro era "um arquipélago de ilhas econômicas isoladas", onde o comércio ocorria principalmente dentro das próprias regiões.

Como consequência "foi apenas após a efetivação de um programa nacional de construção de rodovias nos anos 50 e 60 que o Brasil, rompeu, de fato, com o estado de relativo isolamento de suas economias regionais" (GALVÃO, 1993, p. 524). Todavia, o processo de integração nacional em termos comerciais ocorreu com diferentes condições de integração entre as regiões. Enquanto o comércio das regiões Norte e Nordeste com o restante do país era realizado quase que exclusivamente por cabotagem, até os anos 1940, as regiões Centro-Oeste e Sul já se interligavam por outros meios de transporte.

Assim, do conjunto de informações elencados anteriormente pode-se inferir que até o final da década de 40, as distintas regiões brasileiras não eram comercialmente integradas entre em si, salvo no que diz respeito a alguns fluxos mais importantes: açúcar e algodão do Nordeste para o Rio de Janeiro e São Paulo; gado de Minas Gerais e Centro Oeste para São Paulo e Rio de Janeiro; alimentos do Sul para o Rio de Janeiro e algumas áreas urbanas do Nordeste (CANO, 1988). Portanto, o processo de integração regional do país se dá, sobretudo, a partir da década de 50, quando através da mobilização de investimentos nas áreas de infraestrutura e na ampliação da malha rodoviária, os fluxos inter-regionais de comércio crescem significativamente.

Cano (1985), por seu turno, analisa o comércio inter-regional do estado de São Paulo com o resto do país, no período de 1928 a 1968. As principais observações do autor vão de encontro ao apontado por Galvão (1993, 2014): maior integração do mercado doméstico nacional a partir de 1950, dado que as exportações de São 
Paulo para os demais estados se elevam consideravelmente em relação às suas exportações internacionais.

Subdividindo sua análise em dois períodos, 1928-1950 e 1950-1968, Cano (1985) observa que: i) entre 1928 e 1950, as exportações inter-regionais entre São Paulo e as demais unidades federativas triplicaram. Para tal período o autor enfatiza que o aprofundamento da industrialização do país e as condições externas desfavoráveis fizeram com que o comércio de alimentos e de matérias primas crescesse significativamente, denotando o aumento do grau de interdependência e complementaridade entre as duas regiões, São Paulo e resto do Brasil (CANO, 1985, p. 211-212); ii) no período 1950 a 1968, tal complementaridade se intensifica, vinculada à implantação da indústria pesada e dos investimentos nas áreas de infraestrutura e ampliação da malha rodoviária. Para o período 1955-1968, as exportações internacionais paulistas cresceram 58\%, por outro lado, suas exportações interestaduais aumentaram 505\% em igual período. As importações também seguiram este comportamento, enquanto as importações internacionais aumentaram 98\%, as importações de São Paulo dos demais estados cresceram $176 \%$.

Cano (1988), ao analisar o processo de industrialização do país e a integração do mercado nacional, enfatizada nas análises de Galvão (1993, 2014) e Cano (1985), aponta que esse processo de integração geraria três tipos de efeitos.

Os de estímulo, no sentido de que o avanço da industrialização (concentrada em São Paulo) passava a exigir do resto do país notável esforço de complementaridade agrícola, mineral e industrial, não só pela sua expansão física, mas também porque o abastecimento externo esteve contraído durante o período. Desta forma, os demais estados não apenas aumentavam suas importações de São Paulo, mas também passavam a lhe vender mais.

Os de inibição ou bloqueio, que consistiram no fato de que, instaurado o processo de industrialização em São Paulo, determinadas atividades já lá instaladas, com capacidade e economia de escala para operar a nível nacional, não se repetiriam em outras localidades, bloqueando ali seu surgimento por longo período de tempo.

O terceiro, os efeitos de destruição, poderiam manifestar-se via concorrência entre produtores de distintas regiões. Contudo, o fato de que o mercado nacional tornou-se cativo da indústria nacional, pela longa restrição às importações, de um lado, e, de outro, pela possibilidade de renovar-se o parque fabril, era diminuta a competição ${ }^{10}$.

Isso se traduziu em uma concentração espacial da produção, principalmente dos produtos mais sofisticados e industrializados, nas localidades que lograram o processo de industrialização inicialmente.

\subsection{Da década de 1970 aos anos 90: uma breve descrição da balança comercial interestadual do país}

Pacheco (1998), através do estudo da balança comercial interestadual do país e seus respectivos estados entre 1975 e 1985, verifica que, no período em

\footnotetext{
${ }^{10} \mathrm{O}$ autor aponta que a partir de meados da década de 1950, dado o reequipamento industrial ensejado pelas massivas importações induzidas pela guerra da Coréia, a situação se alterou.
} 
análise, o percentual das operações comerciais (vendas e compras) realizadas com estados de fora da região cresceram em detrimento das operações intarregionais. Nesse caso, conforme informações presentes na Tabela 1, as vendas inter-regionais de $47 \%$ do total em 1969 passam para 67\% em 1985.

Tabela 1. Participação do comércio inter-regional no comércio interestadual das macrorregiões brasileiras no período 1969-1985

\begin{tabular}{l|cc|cc|cc|cc}
\hline \multicolumn{1}{c|}{ Região } & \multicolumn{2}{c|}{1969} & \multicolumn{2}{c|}{1975} & \multicolumn{2}{c|}{1980} & \multicolumn{2}{c}{$\mathbf{1 9 8 5}$} \\
& Vendas & Compras & Vendas & Compras & Vendas & Compras & Vendas & Compras \\
\hline Norte & 60,4 & 82,0 & 91,5 & 96,0 & 91,7 & 93,2 & 88,0 & 90,9 \\
Nordeste & 36,4 & 63,5 & 56,5 & 74,7 & 57,6 & 71,7 & 59,6 & 71,6 \\
Sudeste & 38,4 & 29,3 & 47,2 & 30,5 & 49,3 & 37,5 & 64,5 & 56,2 \\
Sul & 78,8 & 76,5 & 77,1 & 83,2 & 72,7 & 77,2 & 70,4 & 69,1 \\
Centro-Oeste & 90,6 & 96,2 & 76,6 & 92,4 & 86,2 & 93,0 & 83,7 & 91,3 \\
\hline Total & $\mathbf{4 7 , 0}$ & $\mathbf{4 7 , 0}$ & $\mathbf{5 3 , 8}$ & $\mathbf{5 3 , 8}$ & $\mathbf{5 6 , 9}$ & $\mathbf{5 6 , 9}$ & $\mathbf{6 7 , 2}$ & $\mathbf{6 7 , 2}$ \\
\hline
\end{tabular}

Fonte: Pacheco (1998).

Para Pacheco (1998) a explicação para o aumento médio dos índices nacionais de comércio inter-regional passa pela maior integração do Nordeste e Sudeste com o conjunto da economia nacional. No tocante a esse aspecto, o autor chama a atenção para o peso crescente da participação do Nordeste no conjunto das operações comerciais por vias internas do Sudeste, que de uma participação de $8 \%$ em 1975 passa para 14\% em 1985. O autor também mostra que a despeito do ocorrido entre 1943 e 1969, em termos dos respectivos PIBs regionais, para muitos estados brasileiros ocorreu um decréscimo ou estagnação dos coeficientes de comércio por vias internas, à exceção dos estados da Bahia e do Amazonas, respectivamente, devido à instalação do Polo Petroquímico de Camaçari e da Zona Franca de Manaus. Para o autor, o período conjuntural recessivo que caracteriza o início da década de 1980 pode explicar essa reversão no comportamento dos fluxos de comércio interestaduais.

Quanto ao comércio com o exterior, a partir do estudo de Pacheco, verificase, para o período 1980-1990, o crescimento das exportações em boa parte das regiões do país. Para o estado de São Paulo observa-se queda relativa em sua participação, principalmente devido ao aumento das exportações do Centro Oeste (produtos básicos), do Maranhão (semimanufaturados), do Norte (básicos e semimanufaturados) e de Minas Gerais (básicos, semimanufaturados e manufaturados).

Pautando a análise em dados para o início dos anos 90, Pacheco (1998) também mostra a concentração das pautas de exportações para a maioria das regiões. São Paulo e a região Sul são as localidades que apresentam maior diversificação da pauta. Na região Norte, os produtos de origem mineral eram responsáveis por 70,3\% de suas exportações. Já na região Centro Oeste, o complexo produtivo da soja representava $65 \%$ da pauta de exportações regionais.

No caso nordestino o autor chama atenção para a perda de importância das exportações, comparativamente à década de 1970. O mesmo salienta ainda que embora tenham crescido no período as exportações de cacau e seus derivados, caju, cera de carnaúba, sisal e outros produtos regionais, esse crescimento foi insuficiente para compensar a menor importância das exportações de açúcar e 
algodão (PACHECO, 1998). Ademais, também enfatiza a concentração da pauta de exportações nordestina ao apontar, por exemplo, que as exportações de alumínio respondem por $90 \%$ do total das exportações maranhenses, que na Bahia o polo de Camaçari exporta um terço do total estadual, bem como que para o conjunto dos demais estados da região o açúcar representa $36 \%$ das exportações e os derivados do caju $11 \%$.

Castro, Carris e Rodrigues (1999) analisaram o quadro da distribuição do comércio interestadual brasileiro em 1985: suas características, peculiaridades e relações com os diversos setores da economia, bem como dos custos logísticos incorridos nessas relações. A princípio os autores verificam que tal quadro apresentou forte concentração espacial. A maioria das exportações e importações foi realizada por um pequeno número de estados, basicamente concentrados em duas das cinco macrorregiões (Sul e Sudeste) nas quais se divide o território nacional. Poucos também foram os estados que apresentaram superavit na Balança Comercial Interestadual. Apenas os Estados de São Paulo, Rio de Janeiro, Minas Gerais, Paraná, Amazonas e Santa Catarina apresentaram superavits no ano analisado, e foram responsáveis por cerca de $70 \%$ das exportações e $58 \%$ das importações (CASTRO; CARRIS; RODRIGUES, 1999).

Os autores apontam, por exemplo, que o estado de São Paulo era responsável, em 1985, por 32\% das exportações interestaduais, enquanto as regiões Norte, Nordeste e Centro Oeste exportavam juntas, $22,5 \%$ do total nacional. São Paulo também foi o principal destino das importações interestaduais, totalizando $25 \%$ destas, sendo o principal mercado consumidor de quase todos os outros estados da Federação. Quando verificam-se as participaçõos destas localidades no PIB industrial brasileiro, observa-se a elevada concentração espacial da indústria. São Paulo detinha aproximadamente $44 \%$ da produção industrial, enquanto o Nordeste produzia $12 \%$ do total nacional, o Norte, $4 \%$, e o Centro Oeste, $2 \%$. "Essa concentração das relações de comércio refletiu, em certa medida, a elevada concentração espacial da atividade econômica, especialmente industrial, existente no país" (CASTRO; CARRIS; RODRIGUES, 1999, p.353).

Os autores evidenciam a importância da produção industrial ao enfatizar que, à exceção do Rio Grande do Sul, os estados que registraram deficit na balança comercial interestadual apresentavam uma produção industrial pequena, com participações individuais no PIB setorial inferiores a $2 \%$. Assim, essa concentração espacial tem efeito direto no volume de comércio:

[...] sendo os estados superavitários responsáveis por $70 \%$ das exportações e $58 \%$ das importações. Os principais fluxos de comércio ocorreram entre eles próprios e, em segundo plano, entre eles e os deficitários, destacando-se ainda os fluxos entre estados vizinhos. Esse fato revela uma relação de dependência, principalmente por parte dos estados deficitários em relação aos superavitários (CASTRO; CARRIS; RODRIGUES, 1999, p.356).

Ademais, comparando os dados da matriz às participações no PIB nacional dos Estados, Castro, Carris e Rodrigues (1999) encontram relações positivas entre o comércio interestadual da maior parte dos Estados, exceção feita apenas aos 
Estados do Amazonas, Distrito Federal, Mato Grosso, Mato Grosso do Sul e Santa Catarina.

Vasconcelos e Oliveira (2006), por sua vez, realizaram uma análise descritiva da pauta de exportações (vias internas) por atividade econômica, em 1999, para as unidades da Federação. Tal qual o observado a partir da década de 1960, os dados da matriz de 1999 revelam a maior a fração do PIB de cada região que é destinada ao comércio inter-regional, em relação àquela voltada para o comércio com o exterior. Nesse caso, para todas as regiões do país, o valor das suas vendas por vias internas superava, em pelo menos quatro vezes, o valor de suas exportações para o resto do mundo.

Os autores apontam ainda que: i) na região Sudeste, destaca-se o estado de São Paulo, ao responder pela maioria das compras efetuadas pelos outros estados do país. Ademais, há elevada participação das transações deste estado com a própria região Sudeste e a região Sul (66\% do total) em detrimento das demais regiões (34\% do total), corroborando a "desigual distribuição da renda brasileira" (VASCONCELOS; OLIVEIRA, 2006, p. 9); ii) ao analisar-se a região Sul, pode-se auferir que o principal destino das exportações interestaduais dos estados pertencentes a esta região são: em primeiro lugar o estado de São Paulo, que responde por parcela significativa das compras sulinas, e em segundo lugar seus estados vizinhos, ou seja, o comércio intrarregional; iii) o Centro-Oeste é marcado pela concentração das exportações para São Paulo, principalmente, Paraná e Minas Gerais. Ademais, a região apresenta pauta de exportação interestadual fortemente atrelada nas atividades de fabricação de produtos alimentícios, bebidas e agropecuária; iv) quanto aos estados nordestinos, nota-se a predominância do comércio intrarregional, dado que, a exceção do estado da Bahia, as exportações destes estados para as demais macrorregiões do país têm como principal destino a própria região; v) no Norte, o estado do Amazonas destaca-se pela significativa cifra de exportação atrelada aos estados de São Paulo e Rio de Janeiro, principalmente no que se refere à atividade de fabricação de material eletrônico e de aparelhos e equipamentos de comunicações, cifra coerente com a existência das indústrias na Zona Franca de Manaus. Ademais, os principais importadores da região encontramse na região Sudeste.

Ademais, os autores destacam o grande contraste na natureza das transações comerciais entre a região Sudeste e as demais regiões brasileiras. Ao analisar o saldo da balança comercial inter-regional das regiões, em 1999, enquanto o Nordeste registrou um deficit de R\$ 24 bilhões, o Sul de R\$ 15 bilhões, o CentroOeste de R\$300 milhões e o Norte um pequeno superavit de $R \$ 700$ milhões, 0 Sudeste registrou um saldo nas suas transações comerciais inter-regionais de R\$ 39 bilhões. Contraste ainda maior é o apresentado entre o estado de São Paulo e as demais unidades da Federação. Enquanto São Paulo obteve um saldo comercial de $\mathrm{R} \$ 51$ bilhões, apenas três, das 26 demais unidades federativas do país registraram superavit nas suas transações interestaduais: o Amazonas ( $R$ \$ 8,9 bilhões de superavit), o Paraná ( $R \$ 4,6$ bilhões) e o Espírito Santo ( $R \$ 38$ milhões). Ou seja, todos os demais estados apresentavam-se deficitários nas suas relações comerciais inter-regionais em 1999.

Em análise específica para o Nordeste em 2006, Garcia et al. (2012) mostram que a região continuava deficitária nas suas relações comerciais com as demais 
regiões do país e, como em todos os levantamentos anteriores, os maiores deficits relacionavam-se às regiões mais ricas, isto é, o Sul e, principalmente, o Sudeste. O alto grau de concentração nos fluxos das trocas interestaduais da região também se mantém. A Região Sudeste foi a origem de $45,75 \%$ das entradas e destino de $39,71 \%$ das saídas. Tal qual o observado anteriormente, a concentração se deve principalmente às trocas com o estado de São Paulo, responsável por 32,13\% do total das compras interestaduais nordestinas e receptor de $28,21 \%$ das vendas, gerando um saldo negativo de $\mathrm{R} \$ 15.136$ milhões, ou 49,78\% do déficit total.

Assim, resumindo os principais resultados dos trabalhos apresentados nesta seção, observa-se que até o final da década de 40 o sistema comercial brasileiro era "um arquipélago de ilhas econômicas isoladas", onde o comércio ocorria principalmente dentro das próprias regiões. Apenas após a efetivação de um programa nacional de construção de rodovias, na década de 1950, é que se rompe com o estado de relativo isolamento das regiões. Quanto ao padrão que se verifica a partir de 1985, nota-se a preponderância dos fluxos de comércio interestaduais associados às regiões mais desenvolvidas do país, Sul e Sudeste, em especial ao estado de São Paulo.

\section{Fluxos de comércio interestaduais: uma análise da matriz de comércio interestadual brasileira nos anos de 2008 e 2011}

Esta seção procura fazer uma breve descrição do comércio interestadual no Brasil, através da análise dos fluxos de bens e serviços inter-regionais nos anos de 2008 e 2011. A seção contribui a verificação da hipótese lançada ao permitir obter-se uma visão geral do sistema inter-regional e intrarregional do Brasil, dos principais fluxos de comércio e da interdependência comercial entre as regiões analisadas. Salienta-se que através do exame das relações apresentadas nesta seção, mediante a comparação aos trabalhos sumarizados na seção 3, possíveis alterações na distribuição do comércio interestadual brasileiro, podem ser verificadas.

A seção está estruturada da seguinte forma: em primeiro lugar analisa-se como se dá a distribuição do comércio interestadual brasileiro, mediante a análise da participação de cada estado nas exportações e importações domésticas e seus respectivos saldos comerciais e de serviços em 2008. Em seguida, a análise pauta-se no estudo dos fluxos comércio para o ano de 2011. Ademais, considerações acerca da integração comercial entre os estados de uma mesma macrorregião são tecidas.

As informações para construção das análises provêm das matrizes insumoproduto (MIPs) interestaduais de Guilhoto et al. (2010) e Haddad, Gonçalves Júnior e Nascimento (2018), que consistem, respectivamente, na estimação das matrizes de insumo-produto para os vinte e seis estados brasileiros e o Distrito Federal nos anos de 2008 e 2011. Devido ao grande volume de informações necessárias à montagem de um sistema interestadual de insumo-produto, a matriz de 2008 possui como ano base 2004, enquanto para 2011 o ano base é 2010.

Para uma melhor compreensão de algumas das tabelas apresentada nessa seção, as mesmas devem ser interpretadas da seguinte forma: i) no sentido vertical, têm-se as relações de demanda, ou seja, a informação acerca do quanto cada estado importou dos demais; ii) no sentido horizontal, os números associam-se com as relações de oferta, ou seja, com quanto cada estado exportou para o resto do 
país. Ambas as relações são ponderadas pelo total comercializado por vias internas. Dessa forma, pretende-se verificar a importância neste de cada unidade da federação. Ademais, para evitar eventuais distorções entre os distintos momentos em que os dados foram analisados, os mesmos foram inflacionados pelo IPCA de $2010^{11}$.

\subsection{Comércio interestadual em 2008}

O quadro da distribuição do comércio interestadual brasileiro apresentou, em 2008, forte concentração espacial. A maioria das exportações e importações foi realizada pelos estados que compõem as regiões Sul e Sudeste, responsáveis por $73,46 \%$ das exportações e 70,95\% das importações interestaduais. Poucos também foram os estados que apresentaram superavit na balança comercial e de serviços interestadual.

Conforme exposto na Tabela 2, o estado de maior expressão no comércio interestadual foi São Paulo. Em 2008, esse estado respondeu por 33,97\% das exportações interestaduais e por $30,42 \%$ das importações. Em contraponto à alta participação paulista no comércio por vias internas, as regiões Norte, Nordeste e Centro-Oeste - compostas por 20 das 27 unidades federativas - exportaram, juntas, apenas $26,54 \%$ do comércio interestadual. No tocante às importações, $29,05 \%$ do total de importações por vias internas disseram respeito às três regiões em conjunto.

A concentração do comércio interestadual pode ser ressaltada pelo fato de São Paulo ter sido, em 2008, o principal mercado consumidor das exportações de 22 das outras 26 unidades federativas. Por outro lado, não é verificado um estado específico com o qual São Paulo tenha uma ligação comercial muito expressiva. Neste quesito, destacam-se como principais parceiros comerciais desse estado, Minas Gerais, Rio de Janeiro, Paraná, Rio Grande do Sul e Santa Catarina, respondendo juntos por 63,41\% das exportações interestaduais paulistas em 2008.

No contexto do comércio interestadual brasileiro também cabe destacar que os estados de Minas Gerais e Rio de Janeiro, juntos, movimentaram 18,32\% do total de exportações por vias internas do país e $22,13 \%$ das importações.

Tal patamar evidencia, em conjunto aos demais estados da região Sudeste e os estados sulistas, para 2008, tanto a concentração dos fluxos de comércio nas regiões mais desenvolvidas do país como a dependência das regiões menos desenvolvidas, no que concerne ao comércio. Portanto, os dados demonstram que o comércio interestadual brasileiro apresentou-se concentrado em 2008, com os fluxos de comércio direcionados para poucos estados, basicamente os que pertencem às duas regiões mais desenvolvidas do país.

\footnotetext{
${ }^{11}$ Os dados terão como base o ano de 2010, pois o PIB para os estados brasileiros, presentes em algumas análises, encontrava-se nesse padrão.
} 
Tabela 2. Decomposição da participação (\%) dos estados brasileiros no total comercializado por vias internas em 2008

\begin{tabular}{|c|c|c|c|c|c|c|c|c|c|c|c|c|c|c|c|c|c|c|c|c|c|c|c|c|c|c|c|c|c|}
\hline \multirow{2}{*}{\multicolumn{2}{|c|}{ Estado }} & \multicolumn{28}{|c|}{ Relaçōes de Oferta } \\
\hline & & $A C$ & AM & AP & $\mathrm{PA}$ & RO & RR & TO & $\mathrm{AL}$ & $B A$ & CE & $M A$ & PB & $\mathrm{PE}$ & $\mathrm{Pl}$ & $\mathrm{RN}$ & SE & DF & 60 & MS & MT & ES & $M G$ & RJ & SP & $P R$ & $\mathrm{RS}$ & SC & Soma \\
\hline \multirow{28}{*}{ 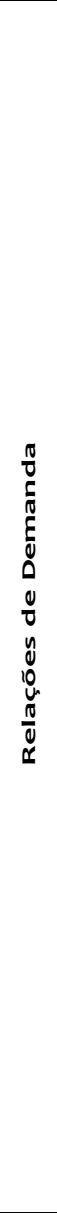 } & $\mathrm{AC}$ & 0,14031 & 0,00119 & 0,00010 & 0,00088 & 0,00040 & 0,00003 & 0,00012 & 0,00033 & 0,00184 & 0,00056 & 0,00024 & 0,00101 & 0,00117 & 0,00028 & 0,00021 & 0,00028 & 0,00224 & 0,00149 & 0,00075 & 0,00148 & 0,00066 & 0,00426 & 0,00320 & 0,00864 & 0,00316 & 0,00355 & 0,00248 & 0,18085 \\
\hline & AM & 0,00231 & 1,00372 & 0,00241 & 0,03161 & 0,00825 & 0,00159 & 0,00377 & 0,00537 & 0,03483 & 0,01592 & 0,01222 & 0,00844 & 0,02370 & 0,00679 & 0,00880 & 0,00758 & 0,02697 & 0,02142 & 0,00899 & 0,01665 & 0,02250 & 0,07275 & 0,11541 & 0,45941 & 0,04044 & 10 & 0,02602 & 03742 \\
\hline & AP & 0,00001 & 0,00107 & 0,15259 & 0,00116 & 0,00002 & 0,00001 & 0,00007 & 0,00007 & 0,00179 & 0,00022 & 0,00020 & 0,0 & 0,00038 & 03 & 0,00009 & 0,000140 & 0,00084 & & 027 & 0,00028 & 0,00054 & 0,00359 & 0,00172 & 0,00534 & 0152 & 0175 & 0,00147 & 0,17587 \\
\hline & PA & 0,00024 & 0,00867 & 0,00072 & 1,16052 & 0,00175 & 0,00021 & 0,00139 & 0,00223 & 0,00754 & 0,00676 & 0,00868 & 0,00382 & 0,00943 & 0,00283 & 0,00311 & 0,00123 & 0,01951 & 0,00578 & 0,00398 & 0,00664 & 0,00739 & 0,02536 & 0,03285 & 0,09395 & 0,02590 & 3073 & 0,02006 & 1,49127 \\
\hline & RO & 0,00106 & 0,01504 & 0,00020 & 0,00296 & 0,38172 & 0,00018 & 029 & 0,00093 & 96 & 0,00204 & 0,00174 & 0,00121 & 0,00290 & 0087 & 081 & 0,00082 & 0,00503 & 0,00355 & 0157 & 0,00403 & 0,00335 & 0,01155 & 0,00897 & 0,03376 & 1606 & 0,01019 & 0,00521 & 0,52197 \\
\hline & RR & 0,00002 & 0067 & 0,00007 & 0,00053 & 0,00014 & 0,11346 & 0,00005 & 0,00011 & 0,00103 & 0,00039 & 0,00019 & 0,00026 & 0,00050 & 0,00023 & 0,00010 & 0,00010 & 0,00127 & 0,00051 & 0,00021 & 0,00035 & 0,00031 & 0,00177 & 0,00220 & 0,00500 & 0,00112 & 0,00112 & 0,00134 & 0,13307 \\
\hline & TO & 0,00005 & 0,00204 & 0,00048 & 0,00518 & 0,00082 & 0,00005 & 0,26854 & 0,00089 & 0,00397 & 0,00422 & 0,00357 & 0,00205 & 0,00431 & 0,00188 & 0,00056 & 0,00065 & 0,01084 & 0,00656 & 0,00123 & 0,00204 & 0,00174 & 0,01665 & 0,01109 & 0,02148 & 0,00505 & 0,00739 & 0,00416 & 0,38750 \\
\hline & AL & 0,00033 & 0,00207 & 0,00024 & 0,00299 & 0,00107 & 0,00011 & 0,00064 & 0,43412 & 0,01740 & 0,00300 & 0,00115 & 0,00253 & 0,01705 & 0,00152 & 074 & 0,00496 & 0,00364 & 0,00363 & 0241 & 0,00375 & 0,00202 & 0,00791 & 0,00752 & 0,03104 & 807 & 990 & 694 & 0,57676 \\
\hline & BA & 0,00175 & 0,01689 & 0,00199 & 0,02127 & 0,00647 & 0,00103 & 0,00442 & 0,01226 & 3,31008 & 0,02284 & 0,01234 & 0,01130 & 0,04176 & 0,00813 & 0,01075 & 0,01779 & 0,03140 & 0,02296 & 0,01248 & 0,02178 & 0,03083 & 0,07383 & 0,06898 & 0,38618 & 437 & 5677 & 0,05122 & 4,30188 \\
\hline & CE & 0,00110 & 0,01135 & 0,00163 & 0,01918 & 0,00316 & 0,00053 & 0,00195 & 0,00367 & 0,03172 & 1,32843 & 0,01454 & 0,01185 & 0,02537 & 0,01557 & 0,01921 & 0,00426 & 0,01423 & 0,01328 & 0,00543 & 2 & 0,00950 & & 0,03619 & 0,10281 & 1737 & 923 & 0,02227 & 1,78587 \\
\hline & MA & 0,00050 & 0,00682 & 0,00071 & 0,02124 & 0,00227 & 0,00030 & 0,00417 & 0,00236 & 0,01792 & 0,00846 & 0,75205 & 0,00281 & 0,01031 & 0,00882 & 0,00319 & 0,00136 & 0,01066 & 0,00952 & 0,00339 & 0,00935 & 0,00470 & 0,03747 & 0,01837 & 0,07581 & 0,01775 & 0,02108 & 0,01285 & 1,06424 \\
\hline & PB & 0,00067 & 0,00170 & 0,00026 & 0,00367 & 0,00066 & 0,00013 & 0,00043 & 0,00223 & 0,00885 & 0,01085 & 0,00209 & 0,59576 & 0,01464 & 0,00130 & 0,00963 & 0,00174 & 0,00427 & 0,00183 & 0,00137 & 0,00151 & 0,00249 & 0,01183 & 0,00822 & 0,03035 & 0,00425 & 685 & 0,00656 & 0,73413 \\
\hline & $\mathrm{PE}$ & 0,00069 & 0,00859 & 0,00089 & 0,01003 & 0,00227 & 0,00049 & 0,00167 & 0,01458 & 0,05449 & 0,02635 & 0,00947 & 0,03201 & 1,74831 & 0,00542 & 0,01376 & 0,00817 & 0,01322 & 0,00687 & 0,00435 & 0,00636 & 0,00872 & 0,02199 & 0,02554 & 0,11496 & 0,01811 & 0,02942 & 0,01362 & 2,20033 \\
\hline & $\mathrm{Pl}$ & 0,00012 & 0,00175 & 0,00029 & 0,00335 & 0,00049 & 0,00008 & 0,00049 & 0,00053 & 0,00378 & 0,00564 & 0,00865 & 0,00059 & 0,00217 & 0,41549 & 0,00044 & 0,00037 & 0,00179 & 0,00189 & 0,00104 & 0,00181 & 0,00132 & 0,00514 & 0,00556 & 0,01749 & 0,00526 & 0,00674 & 0,00395 & 0,49622 \\
\hline & RN & 0,00034 & 0,00576 & 0,00037 & 0,00383 & 0,00081 & 0,00012 & 0,00054 & 0,00070 & 0,02357 & 0,00836 & 0,00130 & 0,00350 & 0,00547 & 0,00143 & 0,57088 & 0,00143 & 0,00218 & 0,00265 & 0,00137 & 0,00199 & 0,00177 & 0,01120 & 0,00549 & 0,06001 & 1208 & 207 & 88 & 0,74409 \\
\hline & SE & 0,00017 & 0,00269 & 0,00031 & 0,00249 & 0,00080 & 0,00013 & 0,00047 & 0,00334 & 0,03573 & 0,00411 & 0,00233 & 0,00133 & 0,00440 & 0,00134 & 0,00126 & 0,41723 & 0,00820 & 0,00480 & 0,00179 & 0,00183 & 0,00356 & 0,01276 & 0,01164 & 0,04802 & 0,01044 & 0,01644 & 0,00575 & 0,60336 \\
\hline & $D F$ & 0,00097 & 0,00923 & 0,00091 & 0,01154 & 0,00338 & 0,00024 & 0,00392 & 0,00157 & 0,02297 & 0,00187 & 0,00434 & 0,00328 & 0,00630 & 0,00340 & 0,00172 & 0,00209 & 3,26571 & 0,03627 & 0,00410 & 0,00245 & 0,00640 & 0,07158 & 0,04811 & 0,03512 & 0,00745 & 0,01250 & 0,01500 & 3,58241 \\
\hline & CO & 0,00164 & 0,01164 & 0,00190 & 0,02458 & 0,00 & 093 & 0,01023 & 0,00634 & 0,02842 & 0,01525 & 0,01101 & 0,00912 & 0,01862 & 0,00631 & 0,00963 & 0,00481 & 09 & 1,95038 & 0,01122 & 0,02642 & 0,01265 & 0,10511 & 0,05113 & 0,23872 & 0,04978 & 4052 & 2443 & 2,71692 \\
\hline & MS & 0,00068 & 0,01173 & 0,00077 & 0,00850 & 0,00228 & 0,00035 & 0,00114 & 0,00242 & 0,01326 & 0,00553 & 0,00446 & 0,00322 & 0,00609 & 0,00264 & 0,00214 & 0,00203 & 0,00659 & 0,00887 & 0,74676 & 0,01553 & 0,00404 & 0,01899 & 0,02597 & 0,13565 & 0,04125 & 0,01648 & 0,02035 & 1,10771 \\
\hline & MT & 0,00139 & 0,01717 & 0,00161 & 0,02116 & 0,00951 & 0,00072 & 0,00236 & 0,00570 & 0,02990 & 0,01411 & 0,01059 & 0,00909 & 0,01739 & 0,00646 & 0,00555 & 0,00532 & 0,01618 & 0,01827 & 0,01721 & 1,05640 & 0,01079 & 0,05128 & 0,05369 & 0,16316 & 0,07456 & 0,03835 & 0,03828 & 1,69620 \\
\hline & ES & 0,00061 & 0,01156 & 0,00105 & 0,00710 & 0,00241 & 0,00033 & 0,00133 & 0,00239 & 0,04291 & 0,00739 & 0,00326 & 0,00381 & 0,01204 & 0,00339 & 0,00273 & 0,00199 & 0,01660 & 0,01079 & 0,00303 & 0,00540 & 1,10758 & 0,09058 & 0,08810 & 0,25785 & 0,03228 & 0,02696 & 0,01229 & 1,75576 \\
\hline & MG & 0,00450 & 0,04683 & 0,00508 & 0,05141 & 0,01419 & 0,00254 & 0,01132 & 0,01461 & 0,11109 & 0,05908 & 0,02875 & 0,02003 & 0,05462 & 0,01501 & 0,01729 & 0,01480 & 0,06076 & 0,10203 & 0,02500 & 0,04137 & 0,11311 & 6,87900 & 0,30637 & 0,95566 & 0,10719 & 0,11299 & 0,07642 & 9,25103 \\
\hline & RJ & 0,00499 & 0,05914 & 0,00535 & 0,06327 & 0,01882 & 0,00250 & 0,01134 & 0,01346 & 0,15213 & 0,03332 & 0,02857 & 0,02256 & 0,05275 & 0,01834 & 0,01939 & 0,01551 & 0,06146 & 0,06976 & 0,03011 & 0,04953 & 0,07816 & 0,29271 & 7,74517 & 0,94496 & 0,21109 & 0,22199 & 0,10215 & 10,32853 \\
\hline & SP & 0,02346 & 0,32663 & 0,02952 & 0,30786 & 0,08912 & 0,01328 & 0,05582 & 0,07595 & 0,64248 & 0,17643 & 0,14413 & 0,10802 & 0,27437 & 0,08602 & 0,09559 & 0,073840 & 0,40048 & 0,39117 & 0,17624 & 0,25961 & 0,28126 & 1,50777 & 1,52111 & 24,60773 & 0,83381 & 0,91642 & 0,55532 & 33,97344 \\
\hline & PR & 0,00561 & 0,03527 & 0,00628 & 0,07294 & 0,01662 & 0,00272 & 0,01143 & 0,01579 & 0,08694 & 0,02774 & 0,02970 & 0,01927 & 0,04293 & 0,01689 & 0,01754 & 0,01491 & 0,04520 & 0,05919 & 0,03719 & 0,06936 & 0,04469 & 0,21353 & 0,22997 & 0,63545 & 4,52158 & 0,18625 & 0,16447 & 6,62945 \\
\hline & RS & 0,00518 & 0,03406 & 0,00477 & 0,06445 & 0,01661 & 0,00250 & 0,01144 & 0,01638 & 0,07993 & 0,04519 & 0,04205 & 0,02123 & 0,04864 & 0,02088 & 0,01888 & 0,01577 & 0,04501 & 0,05917 & 0,02341 & 0,03989 & 0,03988 & 0,17071 & 0,18563 & 0,60278 & 0,14479 & 5,49592 & 0,13743 & 7,39257 \\
\hline & SC & 0,00307 & 0,02333 & 0,00368 & 0,04165 & 0,00934 & 0,00172 & 0,00636 & 0,01037 & 0,05552 & 0,02458 & 0,02084 & 0,01163 & 0,03113 & 0,01030 & 0,01043 & 0,00920 & 0,03020 & 0,03315 & 0,01776 & 0,02270 & 0,02687 & 0,10867 & 0,12776 & 0,35229 & 0,18851 & 0,17236 & 2,77772 & 4,13115 \\
\hline & $\mathrm{ma}$ & 20178 & 7661 & 0,22418 & 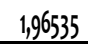 & 0,59842 & 0,14627 & 0,41569 & 0,64869 & 4,82603 & 1,85866 & 1,15848 & 0,90984 & 2,47671 & 0,66156 & 0,84441 & 0,62836 & 4,14556 & 2,84636 & 1,14264 & 1,67453 & 1,82683 & 9,86405 & ו & 3202762 & 6,44324 & 7,53351 & 4,11263 & 100 \\
\hline
\end{tabular}
Fonte: Elaboração própria a partir de dados de Guilhoto et al. (2010). 
No tocante à integração regional, pode-se inferir também a existência de baixa integração comercial entre os estados da região Norte, que mantêm suas principais relações comerciais domésticas vinculadas externamente à região. Tal fenômeno é visível principalmente em relação à região Sudeste, destino de aproximadamente 57,14\% das exportações interestaduais do Norte em 2008.

Ao somarmos todas as exportações dos estados da região Norte para o restante do país, obtemos o total de $94,27 \%$ das exportações de tais estados. Portanto, apenas 5,63\% das exportações da região representam comércio entre seus membros. No que concerne às importações, as mesmas apresentam o mesmo comportamento das exportações, pois 95,13\% das importações dos estados nortenhos, em 2008, advinham das demais regiões do país.

Para a região Nordeste, em 2008, os três estados mais proeminentes no comércio interestadual foram Bahia, Pernambuco e Ceará. Juntos, consumiram R\$ 220,84 bilhões de suas importações transregionalmente, o que equivale a $63,44 \%$ das importações feitas pela região nas demais regiões do país. No que concerne às exportações transregionais da região Nordeste, 66,08\% são referentes aos três estados mencionados.

A análise dos fluxos de bens e serviços interestaduais demandados e ofertados pela região Centro-Oeste, em 2008, denota que, no que concerne a integração comercial, os estados da região apresentam baixa integração regional, tal como as regióes analisadas anteriormente. Apenas 9,80\% do montante de exportações desses estados para o restante do país representam as exportações intraregionais. No tocante as importações, apenas 7,32\% das mesmas representam trocas entre estados da própria região.

Diferentemente das regiões apresentadas anteriormente, a região Sudeste apresenta maior integração comercial regional, dado que a maior parte das exportações e importações dos estados da região representam fluxos de comércio intraregionais. Quanto aos fluxos de exportações e importações para as demais regiões do país, em 2008, destaca-se a região Sul, a qual representa $21,44 \%$ das exportações e $21,87 \%$ das importações da região.

Os estados da região Sul movimentaram 19,81\% das exportações interestaduais do país em 2008. No que concerne às importações, verifica-se dinâmica parecida, pois $19,57 \%$ do total de importações por vias internas no Brasil faziam referência a essa região. No caso das relações internas à região, verifica-se dinâmica similar entre os estados da região. Neste caso, 18,55\% do total exportado domesticamente e $18,77 \%$ do total de importações por vias internas dos estados da região referem-se ao comércio entre seus estados.

Ademais, além de São Paulo, apenas quatro das demais 26 unidades federativas registravam superavit na balança comercial e de serviços em 2008. Nesse caso, o segundo maior superavit registrado foi no Amazonas, a principal razão para o qual relaciona-se à Zona Franca de Manaus, onde se localizam empresas do setor industrial, com destaque para a produção de mercadorias de maior valor agregado - em especial eletroeletrônicos. Também registraram superavit o Paraná ( $R \$ 17,35$ bilhões), Mato Grosso ( $R \$ 2,02$ bilhões) e Santa Catarina ( $R \$ 1,73$ bilhões). 


\section{Gráfico 1. Saldos da balança comercial e de serviços interestadual em 2008 - em R\$̣ milhões de 2010}

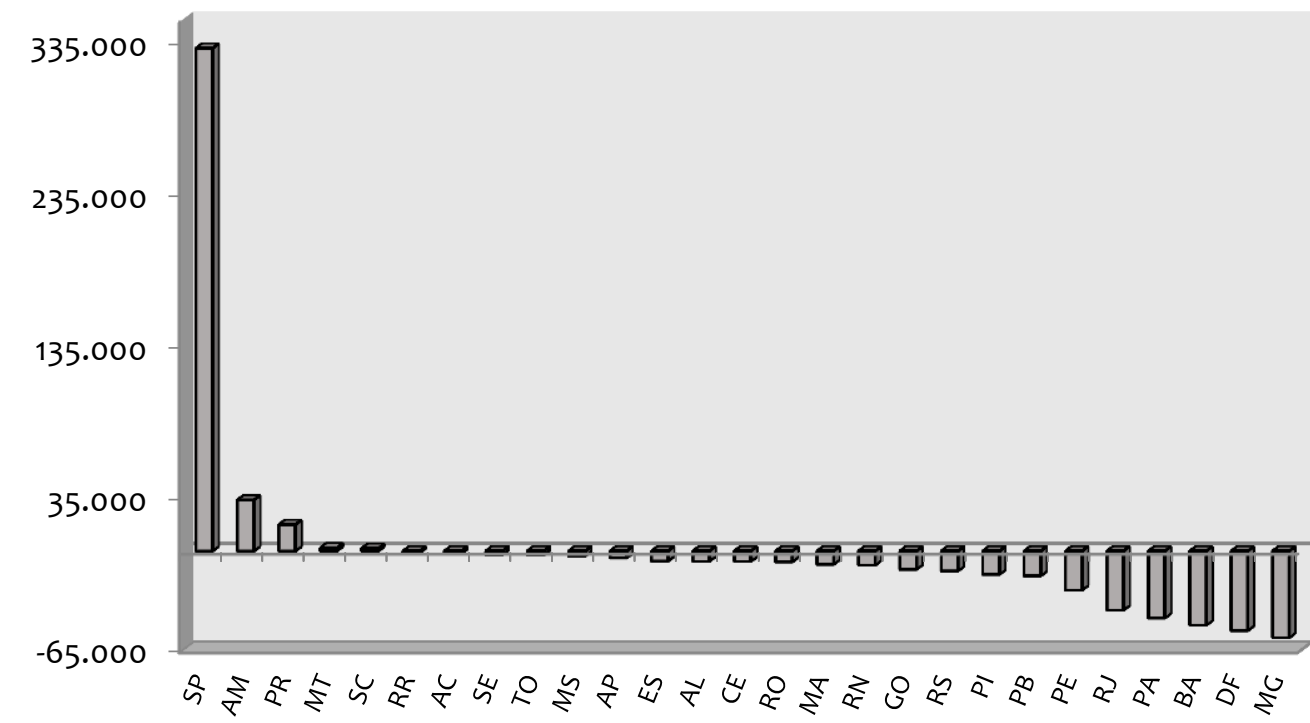

Fonte: Elaboração própria a partir de dados de Guilhoto et al. (2010).

Para os estados em conjunto, em 2008, a região Norte registrou superavit em relação à região Nordeste. O Centro Oeste, por sua vez, obteve superavit com o Norte e Nordeste, enquanto a região Sul apresentou deficit apenas em relação ao Sudeste. O Nordeste, por seu turno, teve deficit nas relações comerciais com as demais regiões.

\subsection{Comércio interestadual em 2011}

Por meio da Tabela 3, observa-se que em 2011 as regiões Norte, Nordeste e Centro-Oeste respondiam por $26,59 \%$ das exportações interestaduais, ao passo que em 2008, 26,54\% delas. Logo, verifica-se uma queda insignificante da concentração nas demais regiões.

Tal ganho participativo no montante de exportações totais é verificado apenas na região Nordeste. Esta obteve uma participação 0,41 p.p. maior que a observada em 2008. A região Norte, comparativamente a 2008, auferiu, em 2011, uma queda participativa de 0,05 p.p.. O Centro-Oeste seguiu dinâmica parecida, já que sua participação nas exportações interestaduais alcançou, em 2011, o patamar de 8,79\%, 0,31 p.p. menor que o verificado em 2008.

No tocante às importações interestaduais das três regiões menos desenvolvidas do país em conjunto, ao contrário do observado para as exportações, em 2011 tem-se queda participativa no montante de importações. Nesse caso, entre os anos analisados, a participação do Norte, Nordeste e Centro-Oeste em conjunto nas importações interestaduais reduz-se em 0,85 p.p.. Consequentemente, em 2011, assim como em 2008, os fluxos de comércio por vias internas no Brasil apresentaram elevada concentração espacial. 
Tabela 3. Decomposição da participação (\%) dos estados brasileiros no total comercializado por vias internas em 2011

\begin{tabular}{|c|c|c|c|c|c|c|c|c|c|c|c|c|c|c|c|c|c|c|c|c|c|c|c|c|c|c|c|c|c|}
\hline \multirow{2}{*}{\multicolumn{2}{|c|}{ Estado }} & \multicolumn{28}{|c|}{ Relaçōes de Oferta } \\
\hline & & $A C$ & $\mathrm{AM}$ & AP & $\mathrm{PA}$ & RO & RR & TO & AL & $B A$ & $\mathrm{CE}$ & $M A$ & PB & $\mathrm{PE}$ & $\mathrm{PI}$ & RN & SE & DF & 60 & MS & MT & ES & $M G$ & RJ & $S P$ & PR & RS & SC & Soma \\
\hline \multirow{28}{*}{$\begin{array}{l}\pi \\
0 \\
0 \\
\tilde{z} \\
0 \\
0 \\
0 \\
y \\
y \\
0 \\
0 \\
0 \\
0 \\
x\end{array}$} & $A C$ & 0,12600 & 0,00625 & 0,00012 & 0,00071 & 0,00213 & 0,00009 & 0,00010 & 0,00029 & 0,00106 & 0,00070 & 0,00035 & 0,00019 & 0,00067 & 0,00011 & 0,000230 & 0,00015 & 0,00220 & 0,00155 & 0,00047 & 0,00125 & 0,00057 & 0,00243 & 0,00279 & 0,01197 & 0,00201 & 0,00318 & 0,00124 & 0,16882 \\
\hline & AM & 0,00515 & 1,11200 & 0,00380 & 0,04021 & 0,01860 & 0,00592 & 0,00371 & 0,00567 & 0,04350 & 0,02033 & 0,01516 & 0,00719 & 0,02659 & 0,00558 & 08970 & 0,00491 & 0,031160 & 0,02506 & 0,00627 & 0,01716 & 0,01645 & 0,04363 & 0,05672 & 0,25590 & 0,02857 & 0,03892 & 0,02215 & 86928 \\
\hline & AP & 0,00012 & 0,00287 & 0,12946 & 0,00147 & 0,00022 & 0,00005 & 0,00019 & 0,00018 & 0,00177 & 0,00086 & 0,00055 & 0,00021 & 0,00077 & 0,00024 & 0,000280 & 0,00018 & 0,001350 & 0,00087 & 0,000220 & 0,00035 & 0,00078 & 0,00259 & 0,00290 & 0,01029 & 0,00150 & 0,00264 & 0,00084 & 16374 \\
\hline & PA & 0 & 0,01948 & 0,00195 & 1,12520 & 0,00375 & 0,00057 & 0,00593 & 0,00265 & 0,01170 & 0,01447 & 0,00780 & 0,00375 & 0,01348 & 0,00538 & 0,004270 & 0,00207 & 0,01523 & 0,01598 & 0,00375 & 0,00823 & 0,00980 & 0,04755 & 0,03177 & 0,16505 & 0,02198 & 0,03397 & 0,01458 & 1,59141 \\
\hline & RO & 0,00341 & 0,02291 & 0,00026 & 0,00302 & 0,41014 & 0,00047 & 0,0003 & 0,00063 & 0,00395 & 0,00262 & 0,00107 & 0,00081 & 0,00280 & 0,00048 & 80,000800 & 0,00065 & 0,003910 & 0,00524 & 0,00227 & 0,00751 & 0,00236 & 0,01222 & 0,01048 & 0,06081 & 0,00882 & 430 & 0,00584 & 0,58811 \\
\hline & RR & 0,00009 & 0,01238 & 0,00003 & 0,00047 & 0,00025 & 0,10459 & 0,00005 & 0,00006 & 0,00041 & 0,00013 & 0,00021 & 0,00007 & 0,00027 & 0,0000 & 30,000080 & 0,00006 & 0,000990 & 0,00043 & 0,00012 & 0,00025 & 0,00023 & 0,00070 & 0,00118 & 0,00434 & 0,00060 & 0,00142 & 0,00038 & 0,12984 \\
\hline & TO & 0,00016 & 0,00352 & 0,00031 & 0,00649 & 0,00074 & 0,00009 & 0,24005 & 0,00074 & 0,00759 & 298 & 0,00427 & 0,00088 & 0,00276 & 0109 & 0950 & 0,00063 & 0,011120 & 0,00647 & 0,00110 & 0,00224 & 0172 & 0776 & 0891 & 3984 & 0498 & 757 & 375 & 6871 \\
\hline & AL & 0,00055 & 0,00675 & 0,00035 & 0,00416 & 0,00096 & 0,00014 & 0,00086 & 0,43070 & 0,03389 & 0,00667 & 0,00309 & 0,00635 & 0,02750 & 0,00169 & 44790 & 0,00565 & 0,007130 & 0,00707 & 0,00129 & 0,00258 & 0,00195 & 0,01224 & 0,00751 & 0,04126 & 0,00354 & 0,00760 & 0,00173 & 0,62805 \\
\hline & BA & 0,00120 & 2028 & 0,00185 & 0,02120 & 0312 & 0 & 0 , & 0,01994 & 2,88773 & 0,04190 & 0,01591 & 1093 & 0,05720 & 433 & 13760 & 0,03559 & 0,10069 & 0,06714 & 0,01240 & 0,03211 & 0,06918 & 72 & 155 & 1226 & 0,04059 & 560 & 029 & 22550 \\
\hline & CE & 0,00108 & 0,01895 & 0,00162 & 0,02241 & 0,00338 & 0,00062 & 0,00349 & 0,00361 & 0,04112 & 1,36390 & 0,02193 & 0,01564 & 0,05025 & 0,01423 & 0,01379 & 0,00249 & 0,236780 & 0,01480 & 0,003450 & 0,00499 & 0,00611 & 0,02971 & 0,01592 & 0,11144 & 0,01524 & 1859 & 0,00577 & 2,04132 \\
\hline & MA & 0,00054 & 1403 & 0,00079 & 0,03157 & 0,00209 & 0,00033 & 1588 & 0,00266 & 0,01415 & 0,01336 & 0,69138 & 0,00337 & 0,00974 & 0,00927 & 3880 & 0,00190 & 0,01074 & 0,00992 & 0,00237 & 86 & 0,00448 & 0,01691 & 0,01829 & 0,08692 & 0,01053 & 829 & 0840 & 0,99566 \\
\hline & PB & 0,00046 & 0,00539 & 0,00043 & 0,00595 & 0,00129 & 0,00018 & 0,00092 & 0,00621 & 0,01596 & 0,01105 & 0,00387 & 0,51295 & 0,04019 & 0,00161 & $0,0,017530$ & 0,00275 & 0,006030 & 0,00458 & 0,00113 & 0,00190 & 0,00373 & 0,01057 & 0,01171 & 0,04330 & 0,00517 & 0,00874 & 00464 & 0,72821 \\
\hline & $\mathrm{PE}$ & 0,00104 & 0,01968 & 0,00121 & 0,01752 & 0,00384 & 0,00068 & 0,00286 & 0,02620 & 0,08303 & 0,03263 & 0,01679 & 0,05592 & 103 & 0,01156 & 32730 & 0,01096 & 0,02866 & 0,01631 & 0,00318 & 0 & 777 & 0,03190 & 0,02531 & 3468 & 0,01273 & 203 & 0,00550 & 2,33168 \\
\hline & PI & 0,00021 & 0,00540 & 0,00039 & 0,00775 & 0,00077 & 0,00016 & 0,00115 & 0,00153 & 0,01038 & 0,00906 & 0,00743 & 0,00151 & 0,00575 & 0,36789 & 0,00275 & 0,00111 & 0,006990 & 0,00436 & 0,00091 & 0,00170 & 0,00277 & 0,00822 & 0,01008 & 0,03420 & 0,00439 & 0,00757 & 0,00360 & 0,50802 \\
\hline & RN & 0,00041 & 0,00987 & 0,00049 & 0,00626 & 0,00081 & 0,00034 & 0,00043 & 0,00173 & 0,02846 & 0,02724 & 0,00484 & 0,02704 & 0,03660 & 0,00237 & 611960 & 0,00232 & 0,00630 & 0,00179 & 0,000430 & 69 & 0,00393 & 0,00621 & 0,02062 & 0,04569 & 0,00404 & 1209 & 0372 & 0,86665 \\
\hline & SE & 0,00043 & 0,00613 & 0,00041 & 0,00543 & 0,00146 & 0,00023 & 0,00075 & 0,00640 & 0,03643 & 0,00629 & 0,00311 & 0,00356 & 0,01243 & 0,00150 & 0,003730 & 0,39318 & 0,007240 & 0,00418 & 0,00101 & 0,00239 & 0,00412 & 0,01011 & 0,01614 & 0,04798 & 0,00589 & 0,01036 & 0,00385 & 0,59475 \\
\hline & DF & 0,00273 & 0,02256 & 0,00195 & 0,02477 & 0,00728 & 0,00107 & 0,00899 & 0,00619 & 0,02883 & 0,02440 & 0,01366 & 0,00618 & 0,02466 & 0,00745 & 0,007990 & 0,00658 & 2,36538 & 0,10367 & 0,00731 & 0,01786 & 0,02458 & 0,08056 & 0,05719 & 0,23219 & 0,02745 & 0,06210 & 0,02614 & 3,19971 \\
\hline & CO & 0,00215 & 0,02568 & 0,00192 & 0,02588 & 0,00802 & 0,00138 & 0,00760 & 0,00529 & 0,02577 & 0,01475 & 0,01231 & 0,00494 & 0,01677 & 0,0048 & 05730 & 0,00471 & 0,11295 & 1,72311 & 0,01074 & 0,02327 & 0,01852 & 0,12129 & 0,06996 & 0,41951 & 0,02409 & 0,04731 & 0,03063 & 2,76910 \\
\hline & MS & 0,00090 & 0,01013 & 0,00062 & 0,00664 & 0,00383 & 0,00042 & 0,00126 & 0,00161 & 0,01119 & 0,00471 & 0,00294 & 0,00178 & 0,00531 & 0,00140 & 0,001880 & 0,00136 & 0,01356 & 0,02002 & 0,75730 & 0,01061 & 0,00618 & 0,02476 & 0,02932 & 0,24076 & 0,02875 & 84 & 20 & 1,23831 \\
\hline & MT & 0,00221 & 0,02639 & 0,00104 & 0,01324 & 0,01353 & 0,00090 & 0,00296 & 0,00341 & 0,02507 & 0,01013 & 0,00575 & 0,00340 & 0,01054 & 0,00245 & 0,003560 & 0,00247 & 0,020120 & 0,03303 & 0,01008 & 1,00329 & 0,00972 & 0,04442 & 0,04621 & 0,19426 & 0,02881 & 0,04503 & 0,02357 & 1,58559 \\
\hline & ES & 0,00076 & 0,01238 & 0,00068 & 0,01437 & 0,00281 & 0,00052 & 0,00176 & 0,00296 & 0,08341 & 0,00566 & 0,00704 & 0,00310 & 0,00817 & 0,00340 & 0,003590 & 0,00255 & 0,01478 & 0,01541 & 0,00415 & 0,00546 & 1,08850 & 0,08688 & 0,22123 & 0,18750 & 0,03037 & 0,02750 & 0,01429 & 1,84924 \\
\hline & MG & 0,00595 & 0,06492 & 0,00465 & 0,05829 & 0,02241 & 0,00321 & 0,01187 & 0,01868 & 0,10755 & 0,04881 & 0,03117 & 0,01712 & 0,06149 & 0,01248 & 0,020460 & 0,01861 & 0,11322 & 0,23188 & 0,03414 & 0,05275 & 0,07828 & 5,98219 & 0,22569 & 1,27940 & 0,13417 & 0,12657 & 0,11128 & 8,88725 \\
\hline & RJ & 0,00263 & 0,04372 & 0,01157 & 0,02432 & 0,01041 & 0,00219 & 0,00908 & 0,01122 & 0,18302 & 0,02523 & 0,01570 & 0,01622 & 0,03392 & 0,01054 & 0,01903 & 0,01133 & 0,118020 & 0,09982 & 0,03036 & 0,04947 & 0,09431 & 0,42283 & 6,88969 & 2,01622 & 0,27430 & 0,21996 & 0,12874 & 10,77387 \\
\hline & SP & 0,02504 & 0,26722 & 0,02479 & 0,23693 & 0,10790 & 0,01675 & 0,06749 & 0,07924 & 0,59776 & 0,21016 & 0,13879 & 0,08685 & 0,25029 & 0,06532 & 20,089900 & 0,06424 & 0,190940 & 0,34785 & 0,31026 & 0,29756 & 0,26801 & 1,73999 & 1,75925 & 23,79206 & 1,70552 & 1,06363 & 0,69042 & 34,49 \\
\hline & PR & 0,00358 & 0,03072 & 0,00239 & 0,02570 & 0,01544 & 0,00194 & 0,00536 & 0,00785 & 0,05499 & 0,02161 & 0,01261 & 0,00848 & 0,02634 & 0,00604 & 0,008780 & 0,00717 & 0,06120 & 0,06031 & 0,03173 & 0,03111 & 0,03738 & 0,12434 & 0,17596 & 1,53074 & 3,83854 & 0,14611 & 0,21005 & 6,48647 \\
\hline & RS & 0,00315 & 0,04502 & 0,00381 & 0,03797 & 0,01698 & 0,00252 & 0,00915 & 0,00936 & 0,07932 & 0,02831 & 0,03001 & 0,01404 & 0,03575 & 0,01202 & 0,01188 & 0,00886 & 0,072850 & 0,07046 & 0,02869 & 0,04425 & 0,03690 & 0,13585 & 0,15464 & 0,85037 & 0,15862 & 4,59634 & 0,16079 & 6,65791 \\
\hline & SC & 0,00099 & 0,01605 & 0,00118 & 0,01083 & 0,00459 & 0,00093 & 0,00416 & 0,00307 & 0,03358 & 0,00684 & 0,01241 & 0,00586 & 0,01033 & 0,00522 & 0,002840 & 0,00364 & 0,033930 & 0,03692 & 0,01334 & 0,01762 & 0,01158 & 0,27944 & 0,06146 & 0,63662 & 0,16876 & 0,20714 & 2,66930 & 4,25861 \\
\hline & ma & 0,19200 & 1,85069 & 0,19808 & 1,77876 & 0,66674 & 0,14726 & 0144 & 0,65808 & 4,45162 & 1,95482 & 1,08014 & 0,81835 & 2,49160 & 851 & 0,896160 & 0,59612 & 2. & 2,92822 & 1,27848 & 1,64642 & 1,80991 & 04080 & דיטמי & 32,88557 & 6,58998 & 6,86540 & 4,20167 & 00 \\
\hline
\end{tabular}

Fonte: Elaboração própria a partir de dados de Haddad, Gonçalves Júnior e Nascimento (2018). 
No que tange ao estado de São Paulo, quando comparados os anos de 2008 e 2011, esse manteve-se como o principal mercado de origem das importações das demais unidades federativas. Por outro lado, não é verificado um estado específico com o qual São Paulo tenha mantido uma concentração comercial expressiva. Um caso claro dessa relação unilateral, em 2011, é o Amapá, cujas importações advindas de São Paulo representavam $34,18 \%$ de suas importações por vias internas, ao passo que era responsável por apenas 0,15\% das importações desse último.

No tocante à integração comercial intrarregional, tal qual o verificado em 2008, o grau de dependência comercial das demais regiões em relação à região Sudeste (em especial ao estado de São Paulo) se mantém elevada em 2011. Novamente observa-se uma grande concentração dos fluxos de comércio originados da porção Centro-Sul do país e que, em geral, os fluxos interestaduais têm importância relativa maior para os estados menos desenvolvidos do país.

\section{Gráfico 2. Saldos da balança comercial e de serviços interestadual em 2011 - em milhões R\$ de 2010}



Fonte: Elaboração própria a partir de dados de Haddad, Gonçalves Júnior e Nascimento (2018).

Quanto ao saldo da balança comercial e de serviços, Gráfico 2, em 2011, nove unidades federativas registravam superavit no comércio interestadual. Nesse caso, o maior superavit registrado, tal qual em 2008, foi em São Paulo, R\$ 60,14 bilhões. $O$ segundo maior foi no Ceará, R\$ 9,82 bilhões. Também registraram superavit comercial os estados de Santa Catarina ( $R \$ 8,24$ bilhões), Paraná ( $R \$ 7,23$ bilhões), Rio Grande do Sul ( $R \$ 4,75$ bilhões), Mato Grosso ( $R \$ 2,73$ bilhões), Goiás ( $R \$ 1,79$ bilhões), Amazonas ( $R \$ 1,67$ bilhões) e Mato Grosso do Sul ( $R \$$ 0,58 bilhões).

Analisados em conjunto, os estados da região Norte, em 2011, registraram superavit apenas em relação à região Nordeste. Para os estados do Centro-Oeste, tal qual em 2008, observa-se superavit com o Norte e Nordeste. A região Sul, novamente, apresentou deficit apenas em relação ao Sudeste. O Sudeste obteve superavit em relação às demais regiões do país, sendo responsável pelo destino de mais de $40 \%$ da pauta de exportações e importações das demais regióes. 0 
Nordeste, por seu turno, teve deficit com as demais regiões nos dois anos observados.

Como observado previamente na seção 3, o quadro da distribuição do comércio interestadual brasileiro manteve-se, em 2011, tal qual em 1985, fortemente concentrado espacialmente. Com os fluxos de comércio relacionados principalmente aos estados das duas regiões mais desenvolvidas do país, sendo estes responsáveis por $73,41 \%$ das exportações e $71,80 \%$ das importações. Portanto, os principais fluxos de comércio ocorreram entre eles próprios e, em segundo plano, entre eles e os demais estados.

Tabela 4. Participações (\%) dos estados no PIB nacional e nos fluxos de comércio em 2008 e 2011

\begin{tabular}{|c|c|c|c|c|c|c|}
\hline \multirow[b]{2}{*}{ Unidades da Federação } & \multicolumn{3}{|c|}{2008} & \multicolumn{3}{|c|}{2011} \\
\hline & $\begin{array}{c}\text { PIB } \\
\text { Nacional }\end{array}$ & $\begin{array}{c}\text { Exportações } \\
\text { interestaduais }\end{array}$ & $\begin{array}{l}\text { Importações } \\
\text { interestaduais }\end{array}$ & $\begin{array}{c}\text { PIB } \\
\text { Nacional }\end{array}$ & $\begin{array}{c}\text { Exportações } \\
\text { interestaduais }\end{array}$ & $\begin{array}{l}\text { Importações } \\
\text { interestaduais }\end{array}$ \\
\hline SÃO PAULO & 33,11 & 34,62 & 21,50 & 32,57 & 34,49 & 32,89 \\
\hline RIO DE JANEIRO & 10,86 & 9,55 & 11,09 & 11,16 & 10,77 & 10,04 \\
\hline MINAS GERAIS & 9,55 & 8,77 & 11,03 & 9,32 & 8,89 & 9,41 \\
\hline RIO GRANDE DO SUL & 6,75 & 7,01 & 7,53 & 6,36 & 6,66 & 6,87 \\
\hline PARANÁ & 5,69 & 7,79 & 7,10 & 5,78 & 6,49 & 6,59 \\
\hline BAHIA & 4,14 & 3,67 & 5,60 & 3,86 & 4,23 & 4,45 \\
\hline SANTA CATARINA & 4,11 & 5,00 & 4,93 & 4,08 & 4,26 & 4,20 \\
\hline DISTRITO FEDERAL & 3,93 & 1,17 & 3,25 & 3,97 & 3,20 & 3,59 \\
\hline GOIÁS & 2,53 & 2,83 & 3,31 & 2,69 & 2,77 & 2,93 \\
\hline PERNAMBUCO & 2,44 & 1,67 & 2,69 & 2,52 & 2,33 & 2,49 \\
\hline ESPÍRITO SANTO & 2,20 & 2,40 & 2,66 & 2,36 & 1,85 & 1,81 \\
\hline PARÁ & 2,12 & 1,22 & 2,98 & 2,13 & 1,59 & 1,78 \\
\hline CEARÁ & 2,05 & 1,69 & 1,96 & 2,12 & 2,04 & 1,95 \\
\hline MATO GROSSO & 1,60 & 2,37 & 2,28 & 1,72 & 1,59 & 1,65 \\
\hline AMAZONAS & 1,58 & 3,82 & 2,49 & 1,56 & 1,87 & 1,85 \\
\hline MARANHÃO & 1,20 & 1,15 & 1,50 & 1,26 & 1,00 & 1,08 \\
\hline MATO GROSSO DO SUL & 1,11 & 1,33 & 1,46 & 1,19 & 1,24 & 1,28 \\
\hline RIO GRANDE DO NORTE & 0,86 & 0,64 & 1,01 & 0,87 & 0,87 & 0,90 \\
\hline PARAÍBA & 0,81 & 0,51 & 1,16 & 0,86 & 0,73 & 0,82 \\
\hline ALAGOAS & 0,64 & 0,53 & 0,79 & 0,69 & 0,63 & 0,66 \\
\hline SERGIPE & 0,62 & 0,69 & 0,78 & 0,63 & 0,59 & 0,60 \\
\hline PIAUÍ & 0,57 & 0,30 & 0,91 & 0,59 & 0,51 & 0,57 \\
\hline RONDÔNIA & 0,55 & 0,52 & 0,80 & 0,67 & 0,59 & 0,67 \\
\hline TOCANTINS & 0,41 & 0,44 & 0,54 & 0,44 & 0,37 & 0,40 \\
\hline RORAIMA & 0,16 & 0,07 & 0,12 & 0,17 & 0,13 & 0,15 \\
\hline ACRE & 0,21 & 0,15 & 0,23 & 0,21 & 0,17 & 0,19 \\
\hline AMAPÁ & 0,21 & 0,09 & 0,26 & 0,22 & 0,16 & 0,20 \\
\hline TOTAL & 100 & 100 & 100 & 100 & 100 & 100 \\
\hline
\end{tabular}

Fonte: Elaboração própria a partir de dados de IBGE (2018), Guilhoto et al. (2010) e Haddad, Gonçalves Júnior e Nascimento (2018).

Conforme pode ser observado na Tabela 4, essa concentração espacial do comércio apresenta estreita relação com a atividade econômica, pois verifica-se que 
existe uma relação positiva entre a participação dos estados no PIB nacional e sua participação nos fluxos de comércio interestaduais. Neste caso, o coeficiente de correlação entre a participação no PIB nacional e nas exportações e importações interestaduais em 2008 é positivo e extremamente forte (coeficiente de Pearson igual a 0,990 e 0,962, respectivamente). No tocante ao ano de 2011, o coeficiente de Pearson é ainda mais forte, respectivamente, 0,999 e 0,998 entre a participação no PIB nacional e a participação nas exportações e importações interestaduais.

A maior participação nos fluxos de comércio interestaduais das regiões Sul e Sudeste, significativamente díspares da observada nas demais regiões, provavelmente está relacionada ao seu maior aproveitamento do processo de integração nacional, ocorrido no decorrer da década de 1950. O que, por sua vez, reflete o processo de formação da economia nacional, dado o avanço da industrialização do país ter se concentrado nessas regiões, principalmente no estado de São Paulo (CANO, 1988; FURTADO, 2005).

A presente análise mostrou que a estrutura de concentração regional do comércio interestadual brasileiro não se modificou significativamente desde 1985 , conforme visto na comparação dos resultados encontrados para o comércio por vias internas para os anos de 2008 e 2011 e os trabalhos sumarizados na terceira seção. Nesse caso, os resultados evidenciam o papel concentrador dos fluxos de comércio, polarizados por São Paulo, que exerce forte influência sobre a estrutura espacial e econômica brasileira. Logo, traçando um paralelo entre as teorias do desenvolvimento desequilibrado e a ênfase dada pelos autores à questão da complementaridade entre as atividades econômicas e regiões, observa-se que o país ainda possui significativos gargalos na promoção de uma maior integração comercial entre as regiões.

\section{Considerações Finais}

Apesar da constatação de que o desenvolvimento é um processo irregular e que potencializa áreas e/ou regiões mais dinâmicas, alguns teóricos do chamado desenvolvimento desequilibrado (FURTADO, 2000; HIRSCHMAN, 1958; MYRDAL, 1968; PERROUX, 1977) chamam atenção para a questão da complementaridade entre as regiões ao apontarem que, quanto maiores os encadeamentos de uma estrutura produtiva e, consequentemente, maior a complementaridade entre atividades e regiões, maior tende a ser o nível de desenvolvimento das mesmas.

Nessa perspectiva, o comércio inter-regional pode tornar-se um propulsor do crescimento regional e/ou perpetuar as disparidades regionais em um determinado território. Logo, é inquestionável a necessidade de um maior número de estudos recentes para tais interações. Nesse sentido, o presente trabalho buscou analisar os fluxos de comércio interestaduais para o país, mediante a observação das relações comerciais inerentes ao próprio estado, bem como as relações concernentes aos demais nos anos de 2008 e 2011.

Da análise empreendida verificou-se que, até o final da década de 40, o sistema comercial brasileiro era "um arquipélago de ilhas econômicas isoladas", onde o comércio ocorria principalmente dentro das próprias regiões, e a pauta de exportações estaduais voltava-se principalmente ao mercado internacional. Após a efetivação de um programa nacional de construção de rodovias, na década de 1950, 
é que se rompe com o estado de relativo isolamento das regiões, e as relações entre os estados se intensificam ao ponto do comércio inter-regional superar o comércio internacional. Observou-se também que o processo de industrialização do país e a integração do mercado nacional, na década de 1950, se traduziram em uma concentração espacial da produção nas localidades que lograram o processo de industrialização inicialmente. Nesse caso, nota-se a preponderância dos fluxos de comércio interestaduais associados às regiões mais desenvolvidas do país, Sul e Sudeste, em especial ao estado de São Paulo.

Pautando a análise para períodos mais recentes, para os anos de 2008 e 2011 é possível evidenciar alguns resultados:

i) na região Norte, observa-se que os estados da região são dependentes do comércio praticado externamente a região, pois aproximadamente $94,27 \%$ das exportações e 95,13\% das importações dos estados da região, por vias internas, representam o comércio com o restante do país. Quanto ao saldo da balança comercial e de serviços da região, em conjunto os estados do Norte são superavitários apenas em relação aos do Nordeste;

ii) para os estados do Nordeste, aproximadamente $76 \%$ de suas exportações e $84,14 \%$ de suas importações interestaduais são relativas ao comércio transregional. Ademais, o Nordeste brasileiro mantém uma relação deficitária com as demais regiões do país;

iii) do montante de exportações e importações dos estados da região Centro-Oeste para os demais estados do país, apenas 9,80\% e 7,32\%, respectivamente, destas representam o comércio intrarregional. Observando-se o saldo da balança comercial e de serviços dos estados da região em conjunto, em relação às demais regiões do país, notam-se superavits em relação ao Norte e ao Nordeste, e deficits com o Sul e, principalmente, o Sudeste;

iv) o comércio intrarregional dos estados do Sudeste responde por 54,9\% de suas exportações interestaduais. No tocante as importações, $51,41 \%$ das mesmas representam trocas comerciais entre os estados do Sudeste. Quanto ao saldo da balança comercial e de serviços da região, o Sudeste mantém superavits em relação às demais regiões;

v) No tocante à região Sul, $81,45 \%$ das exportações interestaduais de seus estados têm como destino as demais regiões do país. Quanto às importações $81,23 \%$ do total importado domesticamente pelos estados da região procedem das demais regiões.

Ademais, chama atenção o grau de dependência comercial das demais regiões em relação à região Sudeste (em especial ao estado de São Paulo). Verificase uma grande concentração dos fluxos de comércio originados da porção CentroSul do país e, em geral, os fluxos interestaduais têm importância relativa maior para os estados menos desenvolvidos do país. Tais observações refletem o processo de formação da economia nacional, dado o avanço da industrialização do país ter se concentrado nessas regiões, principalmente no estado de São Paulo.

Assim, da análise realizada na seção 4 em comparação ao observado na seção 3, tem-se que a estrutura de concentração regional do comércio interestadual brasileiro não se modificou significativamente desde 1985. Tais resultados evidenciam o papel concentrador dos fluxos de comércio, polarizados por São Paulo, que exerce forte influência sobre a estrutura espacial e econômica brasileira. 
Por tratar-se de um mercado com quase 210 milhões de consumidores, a análise dos fluxos de comércio interno do país possibilita a compreensão e avaliação das relações comerciais entre os estados e regiões, a natureza das atividades econômicas, os encadeamentos existentes entre suas estruturas produtivas, bem como o grau de (in)dependência econômica dos mesmos. Portanto, dada observação do caráter ainda concentrador dos fluxos de comércio, é necessária a atuação de políticas públicas que contribuam para a melhoria da integração da economia brasileira. Estas deveriam atuar através da readequação da rede de transportes do país e de estímulos a investimentos que potencializem a complementaridade das unidades da federação e a inserção das regiões menos desenvolvidas no comércio internacional por uma segunda via, já que os mesmos são primordialmente exportadores de bens primários.

\section{REFERÊNCIAS}

ALMEIDA, F. M.; SILVA, O. M. Comércio e integração dos estados brasileiros. Revista de Economia e Agronegócio, v. 5, n. 4, p. 487-499, 2007.

BENKO, G. A ciência regional. Oeiras, Portugal: Celta, 1999.

BREITBACH, A. C. M. Estudo sobre o conceito de região. Porto Alegre, RS: Fundação de Economia e Estatística Siegfried Emanuel Heuser, 1988.

CANO, W. Desequilíbrios regionais e concentração industrial no Brasil: 1930-1970. São Paulo: Global Editora, 1985.

CANO, W. Furtado e a questão regional no Brasil. In: ENCONTRO DE ESTUDOS POPULACIONAIS, 6., 1988, Olinda. Anais [...]. Olinda/PE: ABEP, 1988.

CASTRO, N.; CARRIS, L.; RODRIGUES, B. Custos de transporte e a estrutura espacial do comércio interestadual brasileiro. Revista Pesquisa e Planejamento Econômico, v. 29, n. 3, p. 347-400, 1999.

DINIZ, C. C. A questão regional e as políticas governamentais no Brasil. Belo Horizonte: Cedeplar, 2001. (Texto para Discussão, n. 159).

FURTADO, C. Formação Econômica do Brasil. 32. ed. São Paulo: Companhia Editora Nacional, 2005.

FURTADO, C. Teoria e Política do Desenvolvimento Econômico. 10. ed. São Paulo: Editora Paz e Terra, 2000.

GALVÃO, O. J. A. Comércio interestadual por vias internas e integração regional no Brasil. In: ENCONTRO NACIONAL DE ECONOMIA, 1993, Belo Horizonte. Anais [...]. Belo Horizonte/MG: ANPEC, 1993. 
GALVÃO, O. J. A. Inserção comercial da economia do Nordeste no exterior e no Brasil e proposição de políticas. Mimeo, 2014.

GARCIA, O. L. et al. Relações Comerciais do Nordeste com o Brasil e o mundo.

Cadernos do Desenvolvimento, v. 7, n. 11, p.17-44, 2012.

GUILHOTO, J. J. M.; AZZONI, C. R.; ICHIHARA, S. M.; KADOTA, D. K.; HADDAD, E. A. Matriz de insumo-p do Nordeste e estados: metodologia e resultados. Fortaleza: Banco do Nordeste do Brasil. ISBN: 978.85.7791.110.3. 289 p., 2010.

HADDAD, E. A., GONÇALVES JÚNIOR, C. A., NASCIMENTO, T. B. Matriz interestadual de insumo-produto para o Brasil: uma aplicação do método IIOAS. Revista Brasileira de Estudos Regionais e Urbanos, v. 11, n. 4, pp. 424-446, 2018.

HADDAD, P. R. Tendências recentes do comércio internacional e suas implicações para a economia de Minas. Cadernos BDMG, n. 6, p. 4-63, 2003.

HIRSCHMAN, A. O. The strategy of economic development. Clinton: Yale University Press, 1958.

INSTITUTO BRASILEIRO DE GEOGRAFIA E ESTATÍSTICA - IBGE. Contas Regionais 2002-2016, Rio de Janeiro, 2018.

ISARD, W. Location and space-economy: a general theory relating to industrial location, market areas, land use, trade, and urban structure. Imprenta New York, NY; London: John Wiley: Chapman and Hall, 1956.

LIMA, A. C. C.; SIMÕES, R. F. Teorias do desenvolvimento regional e suas implicações de política econômica no pós-guerra: o caso do Brasil. Revista de Desenvolvimento Econômico, n. 21, p. 5-19, 2010.

MAGALHÃES, A. S. O comércio por vias internas e seu papel sobre crescimento e desigualdade regional no Brasil. 2009. 134 f. Dissertação (Mestrado em Economia) Departamento de Economia, Universidade Federal de Minas Gerais, Belo Horizonte, 2009.

MYRDAL, G. Teoria econômica e regiões subdesenvolvidas. 2. ed. Rio de Janeiro: Saga, 1968.

NURKSE, R. Problems of capital formation in underdeveloped countries. New York: Oxford University Press, 1953.

PACHECO, C. A. Fragmentação da nação. Campinas, São Paulo: IE/UNICAMP, 1998.

PEROBELLI, F. S. Análise das interações econômicas entre os estados brasileiros. 2004. 246 f. Tese (Doutorado em Economia) - Departamento de Economia, Universidade de São Paulo, São Paulo, 2004. 
PEROBELLI, F. S.; HADDAD, E. A., DOMINGUES; E. P. Interdependence among the Brazilian States: an input-output approach. In: ENCONTRO NACIONAL DE ECONOMIA, 2006, Salvador. Anais [...]. Salvador/BA: ANPEC, 2006.

PEROBELLI, F. S. et al. Estrutura de comércio inter-regional no Brasil: uma análise espacial de insumo produto para os anos de 1996 e 2002. Pesquisa e Planejamento Econômico, v. 40, n. 2, p. 281-325, 2010.

PERROUX, F. O conceito de pólo de crescimento. In: SCHWARTZMAN, J. (org.). Economia regional. Belo Horizonte: Cedeplar, 1977. (Textos escolhidos).

RIBEIRO, L. C. S.; BRITTO, G. Interdependência produtiva e estratégias de desenvolvimento para o estado da Bahia. Revista Economia Ensaios, v. 27, n. 2, p. 67-83, 2013.

RODRÍGUEZ, O. La teoría del subdesarrollo de la CEPAL. México: Editora Siglo XXI, 1986.

ROSENSTEIN-RODAN, P. Problems of industrialisation of eastern and south-eastern Europe. The Economic Journal, v. 53, n. 210, p. 202-211, 1943.

SOUSA, E. S.; HIDALGO, A. B. Comércio inter-regional do Nordeste: Análise das mudanças após o desenvolvimento dos recentes polos dinâmicos Revista Brasileira de Estudos Regionais e Urbanos, v. 3, n. 1, p. 9-33, 2009.

VASCONCELOS, J. R.; OLIVEIRA, M. A. Análise da matriz por atividade do comércio interestadual no Brasil: 1999. Rio de Janeiro: IPEA, 2006. (Texto para Discussão IPEA, n. 1159).

André Luís Cabral de Lourenço. Doutor em Economia. Universidade Federal do Rio Grande do Norte - UFRN. Professor do Programa de Pós-graduação em Economia (PPECO) e do curso de Ciências Econômica da Universidade Federal do Rio Grande do Norte. E-mail: andre.Iclourenco@gmail.com.

Joelson Oliveira Santos. Bacharel em Economia. Universidade Federal do Rio Grande do Norte - UFRN. Mestrando no Programa de Pós-graduação em Economia (PPECO) da Universidade Federal do Rio Grande do Norte. E-mail: joelsonsantosrdp@hotmail.com. 
Como citar: LOURENÇO, André Luis Cabral de; SANTOS, Joelson Oliveira. Desenvolvimento regional e complementaridade entre as regiões: Uma análise da matriz de comércio interestadual brasileira nos anos de 2008 e 2011. Redes (St. Cruz Sul, Online), Santa Cruz do Sul, v. 25, p. 2274-2301, 2020. ISSN 1982-6745. doi:https://doi.org/10.17058/redes.v25io.14260.

\section{CONTRIBUIÇÃO DE CADA AUTOR}

André Luís Cabral de Lourenço

- Fundamentação teórico-conceitual e problematização;

- Pesquisa de dados e análise estatística;

- Elaboração e redação do texto;

- Seleção das referências bibliográficas.

Joelson Oliveira Santos

- Fundamentação teórico-conceitual e problematização;

- Pesquisa de dados e análise estatística;

- Elaboração de figuras e tabelas;

- Elaboração e redação do texto;

- Seleção das referências bibliográficas.

Fontes de Financiamento: $O$ presente trabalho foi realizado com apoio da Coordenação de Aperfeiçoamento de Pessoal de Nível Superior - Brasil (CAPES) - Código de Financiamento 001. 